Article

\title{
End-of-Life Recycling Options of (Nano)Enhanced CFRP Composite Prototypes Waste-A Life Cycle Perspective
}

\author{
Fotini Petrakli ${ }^{1} \mathbb{D}$, Anastasia Gkika ${ }^{1}$, Alexandra Bonou ${ }^{1}$, Panagiotis Karayannis ${ }^{1}$, \\ Elias P. Koumoulos 1,2,*(D), Dionisis Semitekolos ${ }^{2}$, Aikaterini-Flora Trompeta ${ }^{2}$, \\ Nuno Rocha ${ }^{3}$, Raquel M. Santos ${ }^{3}$, Guy Simmonds ${ }^{4}$, Glen Monaghan ${ }^{5}$, Giorgio Valota ${ }^{6}$, \\ Guan Gong ${ }^{7}$ and Costas A. Charitidis ${ }^{2}$ (D) \\ 1 IRES-Innovation in Research \& Engineering Solutions, Rue Koningin Astritlaan 59B, \\ 1780 Wemmel, Belgium; fpetrakli@innovation-res.eu (F.P.); agkika@innovation-res.eu (A.G.); \\ abonou@innovation-res.eu (A.B.); karayannisp@innovation-res.eu (P.K.) \\ 2 RNANO Lab.-Research Lab of Advanced, Composite, Nano-Materials \& Nanotechnology, School of \\ Chemical Engineering, National Technical University of Athens, GR-15773 Zographos Athens, Greece; \\ diosemi@chemeng.ntua.gr (D.S.); ktrompeta@chemeng.ntua.gr (A.-F.T.); \\ charitidis@chemeng.ntua.gr (C.A.C.) \\ 3 INEGI-Institute of Mechanical Engineering and Industrial Management \& LAETA-Associated Laboratory \\ for Energy, Transports and Aeronautics, FEUP Campus, Rua Dr. Roberto Frias, 400, 4200-465 Porto, Portugal; \\ nrocha@inegi.up.pt (N.R.); rmsantos@inegi.up.pt (R.M.S.) \\ 4 AP\&M-Anthony, Patrick and Murta Exportacao, Estrada Nacional 120-Falfeira-Lagos, \\ 8600-308 Lagos, Portugal; simmonds.guy@gmail.com \\ 5 GSG—Global Safe Guard Ltd., 2 Longhorsley, Morpeth NE65 8RX, UK; info@globalsafeguard.com \\ 6 Brembo S.p.A, CURNO (Bergamo)—Via Brembo, 25, 24035 Curno, Italy; Giorgio_Valota@brembo.it \\ $7 \quad$ RISE SICOMP AB, Fibervägen 2, 94333 Öjebyn, Sweden; guan.gong@ri.se \\ * Correspondence: epk@innovation-res.eu
}

Received: 24 August 2020; Accepted: 14 September 2020; Published: 18 September 2020

check for updates

\begin{abstract}
Life cycle assessment is a methodology to assess environmental impacts associated with a product or system/process by accounting resource requirements and emissions over its life cycle. The life cycle consists of four stages: material production, manufacturing, use, and end-of-life. This study highlights the need to conduct life cycle assessment (LCA) early in the new product development process, as a means to assess and evaluate the environmental impacts of (nano)enhanced carbon fibre-reinforced polymer (CFRP) prototypes over their entire life cycle. These prototypes, namely SleekFast sailing boat and handbrake lever, were manufactured by functionalized carbon fibre fabric and modified epoxy resin with multi-walled carbon nanotubes (MWCNTs). The environmental impacts of both have been assessed via LCA with a functional unit of ' 1 product piece'. Climate change has been selected as the key impact indicator for hotspot identification ( $\mathrm{kg} \mathrm{CO}_{2}$ eq). Significant focus has been given to the end-of-life phase by assessing different recycling scenarios. In addition, the respective life cycle inventories (LCIs) are provided, enabling the identification of resource hot spots and quantifying the environmental benefits of end-of-life options.
\end{abstract}

Keywords: carbon nano tubes (CNTs); carbon fibre reinforced polymer composite (CFRP); recycling; sustainability; end-of-life (EoL); carbon fibres (CFs)

\section{Introduction}

Composites science and technology are developing rapidly, providing new material solutions, addressing the requirement for high performance [1]. Composites have the ability to be tailored for 
specific end uses; they offer superior properties such as high strength to weight ratios, high flexural and impact strengths, corrosion and heat resistance, durability, dimensional stability, design flexibility, and aesthetics [2]. Fibre-reinforced polymers (FRPs) are among the most widely produced categories of composite materials. The dominant reinforcing fibres used in automotive, aerospace, and marine applications are carbon, glass, and kevlar [3]. In this framework, carbon-based (nano)materials have been widely applied in the fields of environmental science [4-6], food industry [7], new transportation solutions [8], medicine [9] and health applications [10,11], energy [12,13], construction [14], electronics, sports, and so on. In addition, they have gained considerable ground in high-performance applications, such as the aerospace [8,15], marine [16], military [17], and automobile industries [18]. Especially, the last decade has seen a very significant increase in the use of carbon fibre reinforced polymers (CFRPs) [19], as shown in Figure 1.

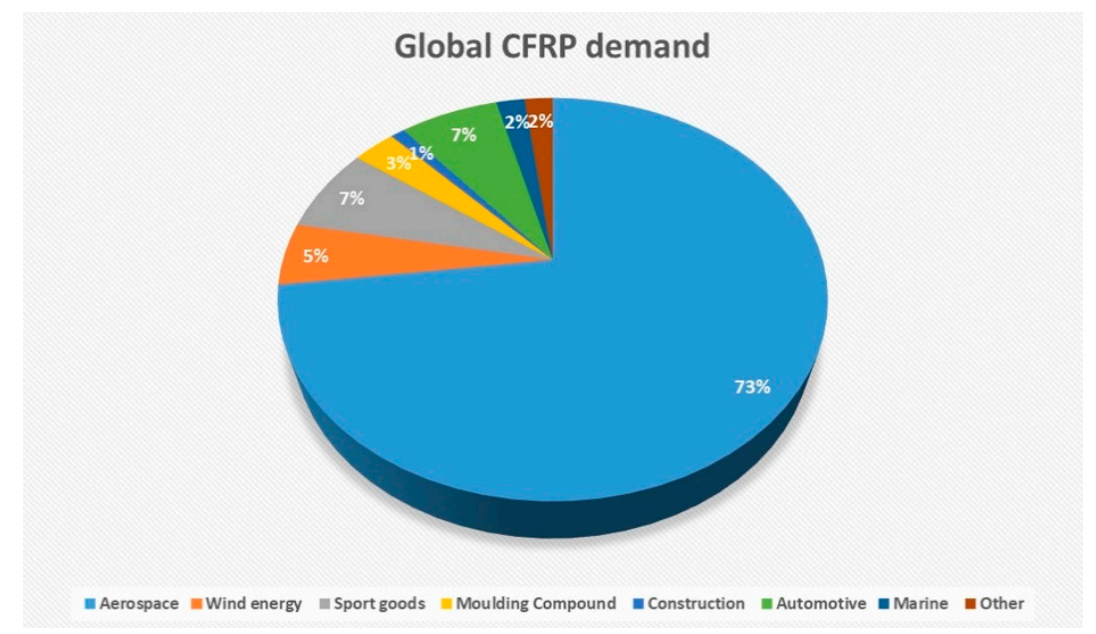

Figure 1. Global demand based on sales (2018) [20]. CFRP, carbon fibre reinforced polymer.

Global demand for carbon fibres (CF) is is expected to increase from 72,000 tonnes to 140,000 tonnes; the CFRP global profit is expected to increase from $\$ 28.2$ billion to $\$ 48.7$ billion [21].

As a result, these endless demands are exacerbating environmental issues such as global warming, climate change, natural resource depletion, waste disposal, loss of biodiversity, deforestation, ocean acidification, ozone layer depletion, acid rain, water pollution, and urban sprawl, which are responsible for environmental damage [22]. Furthermore, the production of CFs causes environmental hazards besides their high costs, which increased the interest in using more sustainable materials [21]. Carbon fibre reinforced polymers exhibit great potential among the other lightweight materials, nevertheless, $\mathrm{CF}$ manufacturing production generates about 15 times more $\mathrm{CO}_{2}$ than the conventional steel on a weight basis [23]. Moreover, virgin carbon fibres ( $\mathrm{vCFs}$ ) require significant energy during manufacturing - between 198 and $595 \mathrm{MJ} / \mathrm{kg}$ [24], approximately 10 times more than other synthetic fibres, such as glass fibres [25]. More specifically, CFs are produced by pyrolysis at $1000-1400{ }^{\circ} \mathrm{C}$ for high-modulus fibres or at $1800-2000{ }^{\circ} \mathrm{C}$ for high-strength fibres [26]. However, as manufacturing processes have progressed, energy consumption has decreased [27]. Much effort has been also applied on the functionalisation of CFs' surface [28], in order to increase the fibre-matrix interface. However, the developed methods, based either on dry [29] or wet chemistry [30], contribute to the increase in environmental impacts, owing to the extra energy consumption and the chemicals used. Another aspect is that the use of recyclable polymers with carbon and other niche fibres renders the composite non-recyclable or, in some cases, non-profitable to be recycled [31]. As a consequence, it is considered a significant issue within the global community, while landfills are filling up at a faster pace along with the need for "going green" as a result of global warming [32]. Landfill is a fairly inexpensive method of disposal, however, based on European Union's Waste Framework Directive, it is the least preferable management option [33]. In this context, the need to ensure the safety of the environment 
and the human health is required. Composite materials could fulfil the demands of sustainability. To tackle these issues, research in recent years has been focused on other eco-friendly options such as green synthesis, processing, applications, recycling, and biodegradation.

The life cycle assessment (LCA) is a vital tool at every stage of a product's life stage from the initial synthesis to the final disposal in order to achieve a sustainable environment. LCA is a state-of-the-art, well-established, and ISO14044 standardised methodology that allows to take into account the entire life cycle of a product or system. By integrating the life perspective into the overall management and driving product and process production in a more sustainable direction, the developer can achieve environmental, occupational health and safety, risk and quality control, as well as green processes and product options [34]. Thus, LCA provides a comprehensive framework for a holistic environmental assessment, which is particularly useful to prevent burden shifting across the life cycle stages (e.g., when lower impacts during the use stage are counterbalanced by higher impacts during production) or across impact categories (e.g., savings in climate change, but burdens regarding resource consumption-ISO 14001) [35,36]. Across the life cycle, LCA makes an inventory of all technical processes and use of resources required to deliver the service provided by the assessed product or system. Then, LCA identifies environmental exchanges (emissions of substances and wastes) occurring to different environmental compartments (like the air, water, and soil) and further translates these exchanges into environmental impacts (such as climate change, ozone depletion, and toxicity to ecosystems and humans).

Regarding nanofibres, the potential human toxicity and ecotoxicity are of major concern [37]. While they are potentially less dangerous as inclusions, free particles within the range of nanometer increase health and environmental concerns owing to their high surface area to mass ratios and their ability to penetrate biological cells $[37,38]$. Carbon nanofibres could exhibit toxic properties similar to those of asbestos however, because of data scarcity, this effect has not yet been considered in LCA studies.

As the European Union (EU) circular economy strategy targets sustainable products in the market to minimize waste, while EU sets a clear vision for climate neutrality by 2050 [39], viable waste management solutions need to be defined for composites. The circular economy plan of the European Commission aims to raise recycling rates and reduce the amount of urban waste that could go to landfill by 2030 to $10 \%$ [40]. In addition, polymer waste management should comply with the existing European Directives and regulations, such as the Landfilling Directive [41], the Packaging Waste Directive [42,43], and the Directives on end-of-life on vehicles (2000/53/EC, 2000), on (waste) batteries and accumulators [44] and on waste electrical and electronic equipment [45]. However, it is not yet clear how this would influence the industrially derived and non-packaging construction waste (of which 75\% must be recycled by 2030 [46]). The emissions target for passenger cars [47] sets a maximum emission limit of $95 \mathrm{~g} \mathrm{CO}_{2} / \mathrm{km}$, averaged by 2020 across a range of manufacturers. This goal is unlikely to be realised just with powertrain and aerodynamic improvements. In order to meet this target, the reduction of vehicle weight with the use of composite materials is crucial. Although, the End-of-Life Vehicle Directive (ELV) [43] requires $85 \%$ by weight of vehicles to be reused or recycled, and $95 \%$ to be reused, recycled, or recovered (including burnt for energy recovery). CFRP composites provide the greatest potential for weight decrease, but their current costs [48] and the lack of a sustainable recycling route are the main challenges to CFRP uptake [49]. The global CFRP waste is expected to be increased at $20 \mathrm{kt}$ annually by 2025 . Approximately $6000-8000$ commercial aircraft will be approaching their end-of-life by 2030 , hence the high demand for CFRPs to establish economically viable waste management and recycling technology [50]. To date, LCA has been employed to characterise the environmental performance of novel CFRPs matrix composite materials in such sectors [51]. Research findings highlight the importance of the end-of-life stage in the overall environmental performance [52], as recyclability aims significantly to consider avoidance (or at least partial replacement) of virgin raw material production with corresponding environmental savings. It is also aligned to the EU policy 
mandate for transitioning towards a circular economy [53]; nonetheless, the quality of the secondary product (recycled CFRP-rCFRP) is still unclarified.

From the available technologies, pyrolysis has been described as the most promising recycling solution for CFRPs, in terms of efficiency [54]. However, several approaches have been also developed to reclaim CFs from CFRPs such as the following [31,55,56]: mechanical recycling, incineration, thermal pyrolysis and fluidized bed process, chemical recycling based on supercritical solvents, and solvolysis. It should be mentioned that these approaches are rather energy intensive, in addition to releasing highly toxic gases [54].

Currently, landfill and incineration with energy recovery (approximately $30 \mathrm{MJ} / \mathrm{kg}$ [57]) are the two commonly used waste treatment methods concerning CFRPs [58]. Both methods are not considered as recycling processes, as they do not incorporate the recovery operation. According to the recent literature, $38.4 \mathrm{MJ} / \mathrm{kg}$ is consumed in order for CFRP to be recycled with the chemical method [25]; this is equivalent to $10 \sim 30 \%$ of the total energy required to manufacture virgin fibres. The energy footprints of the chemical recycling in comparison with the pyrolysis is six time smaller, while the greenhouse gas (GHG) emissions are $1196.22 \mathrm{~g} \mathrm{CO}_{2}$-eq and $5916.08 \mathrm{~g} \mathrm{CO}_{2}$-eq for chemical recycling and pyrolysis, respectively $[59,60]$. Moreover, despite the fact that mechanical recycling is considered as a cost-effective process, the mechanical performance of the reclaimed chopped fibres is significant low, because of the lack of control in terms of length, length distribution, surface quality (adhesion into the novel composite), or origin (different producers) [31]. The energy required to recycle CF by the mechanical method $(0.27-2.03 \mathrm{MJ} / \mathrm{kg})$ is lower in comparison with the energy required to manufacture virgin CF (183-286 MJ/kg). In addition, using pyrolysis and fluidized bed processes, only $70-75 \%$ of the strength retention in the reclaimed fibres is recovered [54]. Thermal recycling methods for CFRP include a high temperature in order to break down the matrix fibre and obtain the fibres. These methods are known as pyrolysis and fluidized bed recycling or their variations. Th pyrolysis process has an energy consumption of around $30 \mathrm{MJ} / \mathrm{kg}$ CFRP and is considered average compared with the other widely adopted industrial processes [54]. Recycling of CFRPs is also influenced by the polymer matrix properties; thermoset polymers are mainly used as matrix for structural CFRPs, representing around $80 \%$ of polymer matrix composites. The solvolysis process has a 78 times greater human health impact, 76 times greater ecotoxicity, 17 times greater carbon footprint (global warming), and 3 times greater ozone depletion in comparison with pyrolysis [61]. The size-decrease alternative method using high voltages, although not being energy efficient (requires $19 \mathrm{MJ} / \mathrm{kg}$ for fibre recovery), shows a strong potential for future growth because it allows for the recovery and reuse of organic resinous products [62]. Such methods are the electrodynamical fragmentation (EDF), in which a high voltage pulse (50-200 kV) passes into ionised water and decomposes the CFRP waste into smaller parts; and high voltage fragmentation (HVF) with a high voltage pulse $(160 \mathrm{kV})$, which also decomposes the CFRP waste into smaller parts. In both methods, clean and long fibres are received [63]. In Table 1 , the energy required for the recycling of $1 \mathrm{~kg}$ CFRP waste using different recycling routes is summarised.

Table 1. Energy required (MJ) in order to recycle $1 \mathrm{~kg}$ carbon fibre reinforced polymer (CFRP) using different routes.

\begin{tabular}{ccc}
\hline CFRP Recycling Routes & Energy Consumption MJ/kg CFRP & Reference \\
\hline Mechanical & $0.17-1.93$ & {$[64]$} \\
Mechanical & $0.27-2.03$ & {$[55]$} \\
Pyrolysis & $3-30$ & {$[64]$} \\
Solvolysis & 19.2 & {$[62]$} \\
Chemical & $60-90$ & {$[65]$} \\
\hline
\end{tabular}

Overall, the high demand of lightweight products causes the wide use of CFRP matrix composites; however, energy intensity, cost, and final disposal remain major barriers to the wide adaptation of these materials for industrial applications. In addition, it has to be mentioned that nanoadditivated 
composites make LCA rather difficult because of data scarcity, as well as inherent composite properties such as good mechanical robustness and stability; this makes detachment, sorting, separation, and so on more difficult when seeking recycling/repurposing. In this study, recycling scenarios are discussed as environmental preferable options for global warming potential (GWP) regarding CFRP wastes, indicating the potential benefits of CFRP recycling in comparison with other disposal routes. By performing an LCA of the new materials, this study aims to investigate what are the environmental hotspots for further environmental improvements. It also aims to showcase the usefulness of LCA as a tool for sustainable innovation in new product development. The suggested perspective aims to assist stakeholders (e.g., producers and policy makers) in making more informed decisions, for example, for better performance regarding environmental performance and better quality control [34]. CFRP has become the preferred choice of material in sectors such as sporting goods and automotive thanks to its lightweight and high-performance properties. However, the rapid development of CFRP will result in increased CFRP wastes disposal in landfills that takes no advantage of the residual value, but adds burden to waste management [21]. In order to address this problem, various recycling methods, such as mechanical recycling and pyrolysis, have been compared in this study, providing recycling recommendations for decision making in industries. Two differed cases have been studied, (a) SleekFast sailing boat and (b) handbrake lever, for motorcycles. Both were manufactured with new developed carbon-based composite materials using different production technologies (hand layup and vacuum bagging and direct infusion molding process, respectively).

\section{Methodology}

For the description of the methodology and LCA calculation as such, the International Reference Life Cycle Data System (ILCD) Handbook suggested by the European Commission [66] is followed.

\subsection{Goal and Scope}

As a first step, the goal (i.e., the purpose) and scope (i.e., what to analyse and how) were identified. The goals of the LCAs and the intended applications coincide with the research objectives presented in the introduction. In terms of scope, the functional unit (FU), which reflects the primary function of the system, was defined as " 1 piece SleekFast sailing boat $13.5 \mathrm{ft}$ long and $5.5 \mathrm{ft}$ wide" with a lifetime of 30 years; and a " 1 piece of handbrake lever" for motorcycles with a lifetime of 20 years.

The system boundaries (Figure 2) consist of the life cycle of the products from the extraction of raw materials to the end-of-life (EoL). As these are descriptive studies aiming to document the analysed systems, the modelling principle for the life cycle inventory followed an attributional LCA approach [66], while multi-functionality of processes is addressed by use of system expansion. For example, in the waste treatment stage, incineration and recycling lead to energy and materials recovery, avoiding respective production from virgin sources.

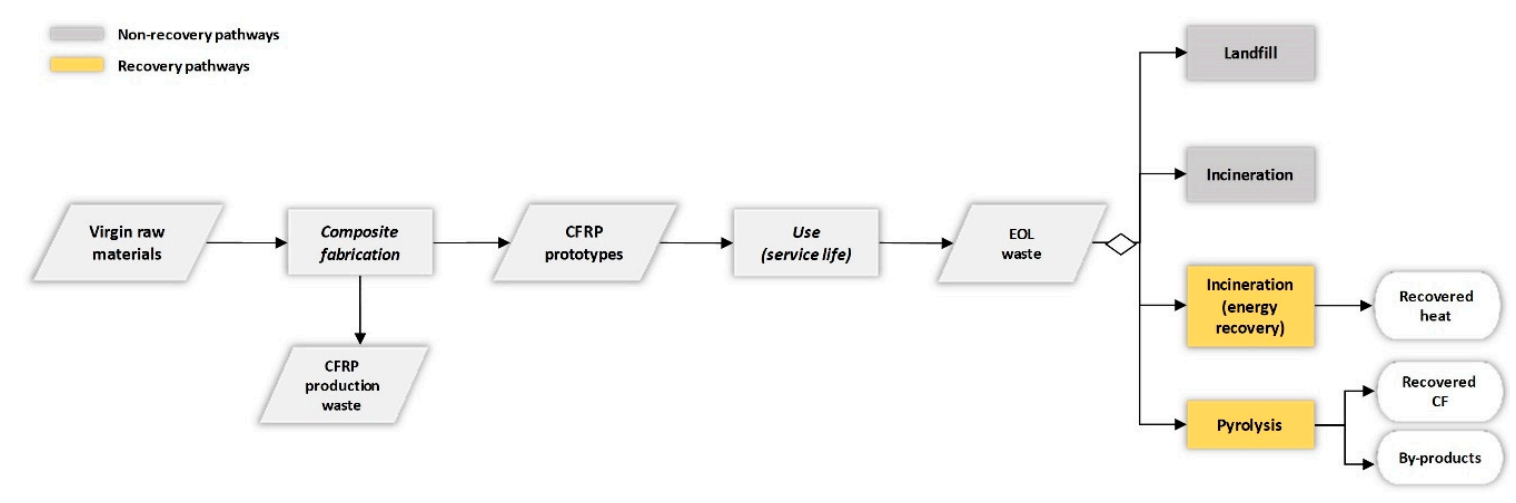

Figure 2. System boundaries considered for both CFRP prototypes: the SleekFast sailing boat and the handbrake lever. EOL, end-of-life. 


\subsection{Inventory Data Collection}

To ensure technological and market representativeness, primary data were collected from both material developers and industry. Detailed accounts of primary inventory data are given in Supporting Information (Appendix A), while the aggregated inventory is given in Table 2 per life cycle stage. In order to model the background processes, for example, extraction of the materials, waste treatment, and so on, the study relied on generic data from ecoinvent v3.4 without technological adjustment [67].

\subsubsection{SleekFast Sailing Boat Case}

Raw materials included modified SICOMIN SR1500 epoxy resin, with multiwall carbon nanotubes (MWCNTs), and piles of commercial CF fabric that has undergone electropolymerisation with polymethacrylic acid, according to the procedure described by [30] and [68], in order to increase the affinity of the fibres with the matrix and to enhance the mechanical properties of the structure. The boat has been manufactured with the hand-layup technique. Production scrap during the manufacturing stage of the composite prototype was set at $6 \%$ of the total mass. This is in line with literature studies, recognizing that production scrap can reach up to $10 \%$ [69]. For the use stage, a $50 \%$ service life extension has been assumed, while there is no repairing requirement. This is a realistic assumption based on typical use stage conditions (intensive care practice for the specific boat type). For maintenance, the assumption is that there is a need for $30 \mathrm{~kg}$ of epoxy gel coat $(2 \mathrm{~kg}$ biannually).

\subsubsection{Handbrake Lever for Motorcycle Case}

Raw materials included epoxy resin and CNT deposited on CF fabric (C-Weave 400T 6K HS $\mathrm{X} 125 \mathrm{CM}$ ) via electrophoretic deposition (EPD). The handbrake lever was manufactured by hand layup followed by wet compression moulding. Production scrap during the manufacturing stage of the composite prototype was assumed as $2 \%$ (as trimming waste) owing to the small size of handbrake lever. The use phase in the case of handbrake lever was not taken into consideration. However, the service life time of the handbrake lever would coincide with the operational life time of the motorcycle.

\subsubsection{Assumptions Applicable for Both Test Cases}

For the carbon fibre production, representative data of industrial process including polyacrylonitrile (PAN) production and relative flows are used [70]. As Japan is the main global supplier of CF and PAN precursor production [71], the corresponding production processes were modelled using the Japanese electricity grid mix, because this is where $70 \%$ of global production takes place [72]. A prior pre-treatment to reduce the size of composite waste is required before any other waste treatment, thus an industrial shredder consuming $0.27 \mathrm{MJ} / \mathrm{kg}$ was assumed [55]. As CFRP prototypes have been demonstrated by consortium partners located in Europe, energy for recycling facilities (pyrolyzer) is modelled using the EU-27 electricity grid mix. Landfill is considered as the reference EOL, as it is the dominant waste management pathway to date $[73,74]$. 
Table 2. Aggregated inventory per life cycle stage and related assumptions *. CF, carbon fibre; MWCNT, multi-walled carbon nanotube; MSW, municipal solid waste.

\begin{tabular}{|c|c|c|c|c|}
\hline & Materials & Manufacture & Use & End-of-life \\
\hline $\begin{array}{c}\text { Sleekfast } \\
\text { sailing boat }\end{array}$ & $\begin{array}{c}\text { Input } \\
\text { CF }=10.5 \mathrm{~kg} \\
\text { Sicomin SR1500 }(0.06 \mathrm{wt} \% \\
\text { MWCNTs) }=10 \mathrm{~kg} \\
\text { PVC foam }=1.5 \mathrm{~kg} \\
\text { Epoxy gelcoat }=4 \mathrm{~kg} \\
\text { Electricity }=368 \mathrm{MJ} / \mathrm{kg} \mathrm{CF} \\
\text { Electricity }=1104 \mathrm{MJ} / \mathrm{kg} \mathrm{CNTs} \\
\text { Output } / \text { emissions to air/water } \\
\text { (see Table A2 in Appendix A) }\end{array}$ & $\begin{array}{l}\text { Scrap waste } \quad(6 \%) \\
\text { hazardous incineration } \\
\text { Aux. waste }(96 \%) \text { hazardous } \\
\text { incineration and } 4 \% \text { recycling } \\
\text { of plastic }\end{array}$ & $\begin{array}{c}\text { Input } \\
\text { Epoxy gelcoat }=30 \mathrm{~kg} \text { (for } \\
\text { maintenance, } 2 \mathrm{~kg} \text { biannually } \\
\text { for } 30 \text { years' lifetime) }\end{array}$ & $\begin{array}{c}\text { Scenario 1: Landfill } \\
\text { Input } \\
100 \% \text { inert waste }[75] \\
\text { Electricity }=0.27 \mathrm{MJ} / \mathrm{kg} \\
\text { Scenario } 2: \text { Hazardous waste } \\
\text { incineration } \\
\text { Input } \\
\text { Electricity }=0.27 \mathrm{MJ} / \mathrm{kg} \\
\text { Scenario 3: } \text { MSW incineration with } \\
\text { energy recovery } \\
\text { Input } \\
\text { Electricity }=0.27 \mathrm{MJ} / \mathrm{kg}\end{array}$ \\
\hline $\begin{array}{c}\text { Handbrake } \\
\text { lever }\end{array}$ & $\begin{array}{c}\text { Input } \\
\mathrm{CF}=0.12 \mathrm{~kg} \\
\text { Epoxy resin }=0.02 \mathrm{~kg} \\
\mathrm{CNTs}=0.01 \mathrm{~kg} \\
\text { Electricity }=368 \mathrm{MJ} / \mathrm{kg} \mathrm{CF} \\
\text { Electricity }=1.1 \mathrm{MJ} / \mathrm{kg} \mathrm{CNTs} \\
\text { Output/emissions to air } / \text { water } \\
\text { (see Table A1 in Appendix) }\end{array}$ & $\begin{array}{c}\text { Input } \\
\text { Pack. mat. }=1.272 \mathrm{~kg} \\
\text { Electricity }=18 \mathrm{MJ} \text { (curing) } \\
\text { Manufacture waste } \\
\text { - } \quad \text { Scrap waste }(2 \%) \text { treated as } \\
\text { MSW (incineration) } \\
\text { - } \quad \text { Pack. waste }(100 \%) \text { is recycled }\end{array}$ & $\begin{array}{ll}\text { - } & \text { service lifetime of } \\
\text { handbrake lever equals to } \\
\text { motorcycle lifetime }\end{array}$ & $\begin{array}{c}\text { Avoided products } \\
\text { Electricity }=3.1 \mathrm{kWh}[76] \\
\text { Heat for reuse }=32 \mathrm{MJ} / \mathrm{kg}[77] \\
\text { Scenario 4: Recycling via pyrolysis } \\
\text { Input } \\
\text { Electricity }=0.27 \mathrm{MJ} / \mathrm{kg} \\
\text { Electricity }=30 \mathrm{MJ} / \mathrm{kg}[61] \\
\text { Avoided products } \\
\text { CF recovery } 60 \%[78] \\
\text { Heating oil }=30 \mathrm{MJ} / \mathrm{kg}[77]\end{array}$ \\
\hline
\end{tabular}

${ }^{*}$ More details are provided in Tables A1 and A2 in Appendix A. 


\subsection{Scenario Analysis for the End of Life Stage}

The EoL of composite materials is associated with uncertainties due to temporal aspects (long life time) and the difficulty in predicting future markets. Uncertainty is enhanced by the lack of inventory data for technologies such as recycling of carbon fibres. Policy wise, in the EU, the political targets such as those set by the Waste Framework Directive aim at high recycling rates, for example, there was the unmet target for $70 \%$ recycling of non-hazardous construction and demolition (C\&D) waste by 2020 [79]. Thus, researchers have concluded on pyrolysis of CFPR waste management $[75,80,81]$ and, experimentally, solvolysis [82-84] as the most promising recycling options up to date. In addition, the high value of CFs and the tightening legislation on disposal were also to enhance this initiative [85]. Given both the uncertainty of the EoL stage and its potential for improving the overall environmental performance of the CFRP, the reference EoL scenario was compared with three alternative EoL scenarios, as shown in Figure 3 and Table 3.

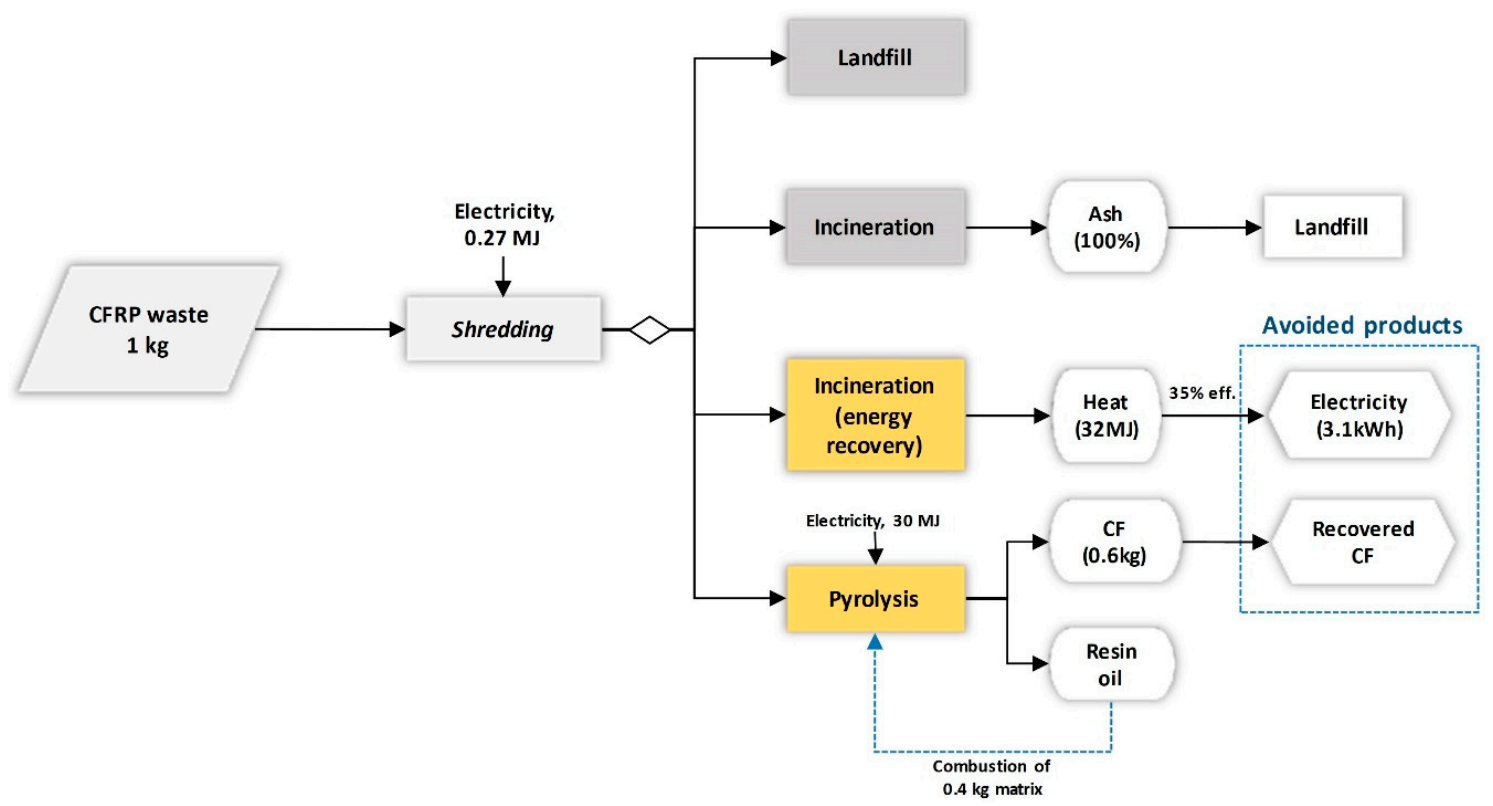

Figure 3. End-of-life (EOL) treatment scenarios for the composite products (values given per kg product waste).

Table 3. The four end-of-life (EoL) scenarios and the respective waste treatment technology applied.

\begin{tabular}{cccc}
\hline Scenario & Waste Management & Waste Treatment Technology & Comments \\
\hline Scenario 1 & $\begin{array}{c}\text { Landfill } \\
\text { Incineration of } \\
\text { hazardous waste }\end{array}$ & $\begin{array}{c}\text { Sanitary landfill } \\
\text { Rotary kiln }\left(>1100{ }^{\circ} \mathrm{C}\right)\end{array}$ & $\begin{array}{c}100 \% \text { inert waste }[75,86] \\
100 \% \text { bottom ash sent to } \\
\text { hazardous landfill }\end{array}$ \\
Scenario 3 & $\begin{array}{c}\text { Incineration with energy } \\
\text { recovery }\end{array}$ & MSW incinerator $\left(850{ }^{\circ} \mathrm{C}-1200{ }^{\circ} \mathrm{C}\right)$ & $\begin{array}{c}35 \% \text { heat recovery convert to } \\
\text { electricity }[75]\end{array}$ \\
Scenario 4 & Thermal recycling & Pyrolysis $\left(450{ }^{\circ} \mathrm{C}\right.$ and $\left.700{ }^{\circ} \mathrm{C}\right)$ & $\begin{array}{c}60 \% \mathrm{CF} \text { recovery and retrieved } \\
\text { energy of } 40 \mathrm{MJ} / \mathrm{kg} \mathrm{matrix}[75]\end{array}$ \\
\hline
\end{tabular}

\subsection{Impact Assessment Indicators}

Of primary interest was the system's contribution to climate change. This was assessed via the IPCC findings [87]. In addition to climate change, all ILCD 2011 Midpoint+ recommended impact categories [88] at a midpoint level were assessed (see Figure 4). The systems were modelled in SimaPro software 8.0.4.26, which is one of the commercial LCA software packages. Uncertainties due to the combined effect of software and database choices are expected to influence the final results, 
however, they are not expected to change the conclusions made based on the primary environmental indicator selected (carbon footprint) $[89,90]$.

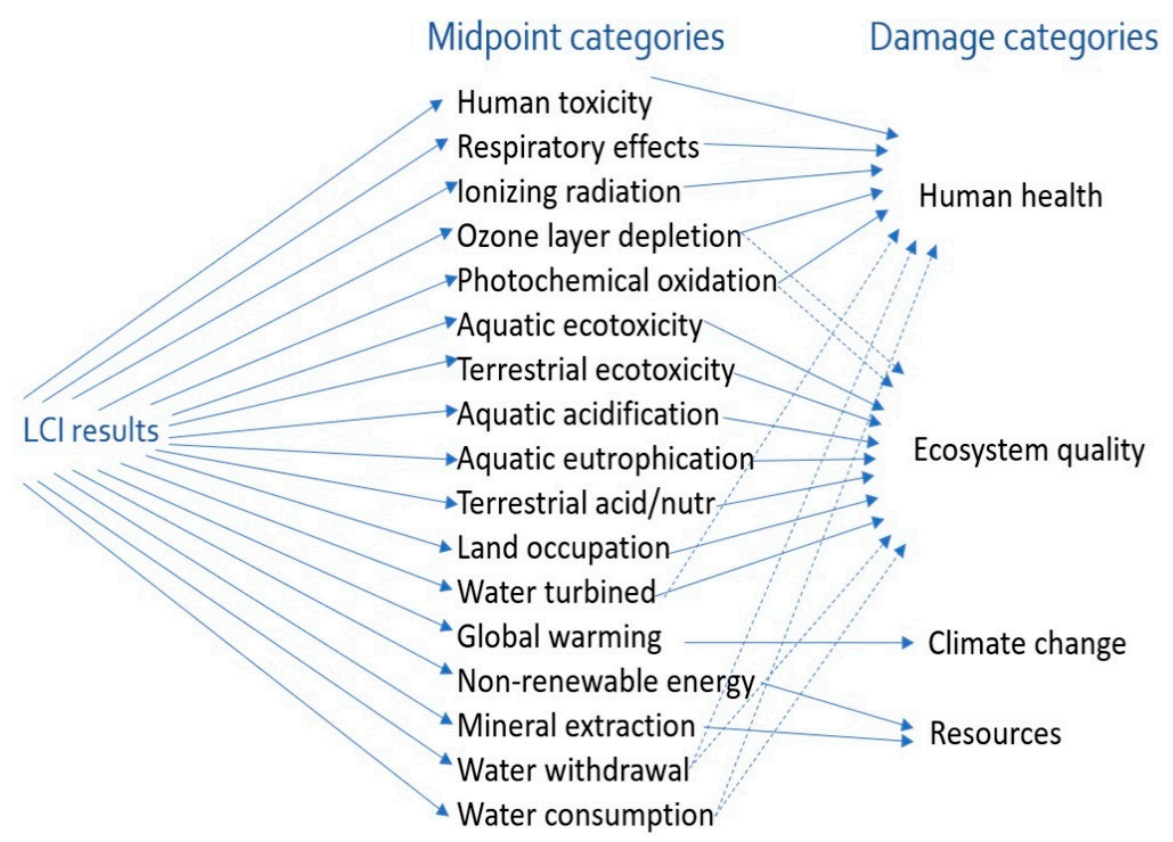

Figure 4. Mid- and end-point environmental impact categories assessed [91]. LCI, life cycle inventory.

\section{Results and Discussion}

The LCA results were used to identify hotspots in two dimensions: across the life cycle of the product and within each life cycle stage to the maximum resolution level according to the available data. As Figure 5 shows for climate change, most of the impacts are due to extraction and production of materials (hereafter called 'materials'). This stage contributes more than $65 \%$ and $70 \%$ to the climate change impact for the boat and the lever case, respectively, followed by the manufacture stage (approximately $30 \%$ for both studied cases). These results are in line with relevant work of the literature [92-94]. The reference EOL scenario has a minor contribution to climate change, mainly owing to the assumption that composite waste behaves as inert material in a landfill, thus a negligible contribution to methane emission is considered over the years $[95,96]$.

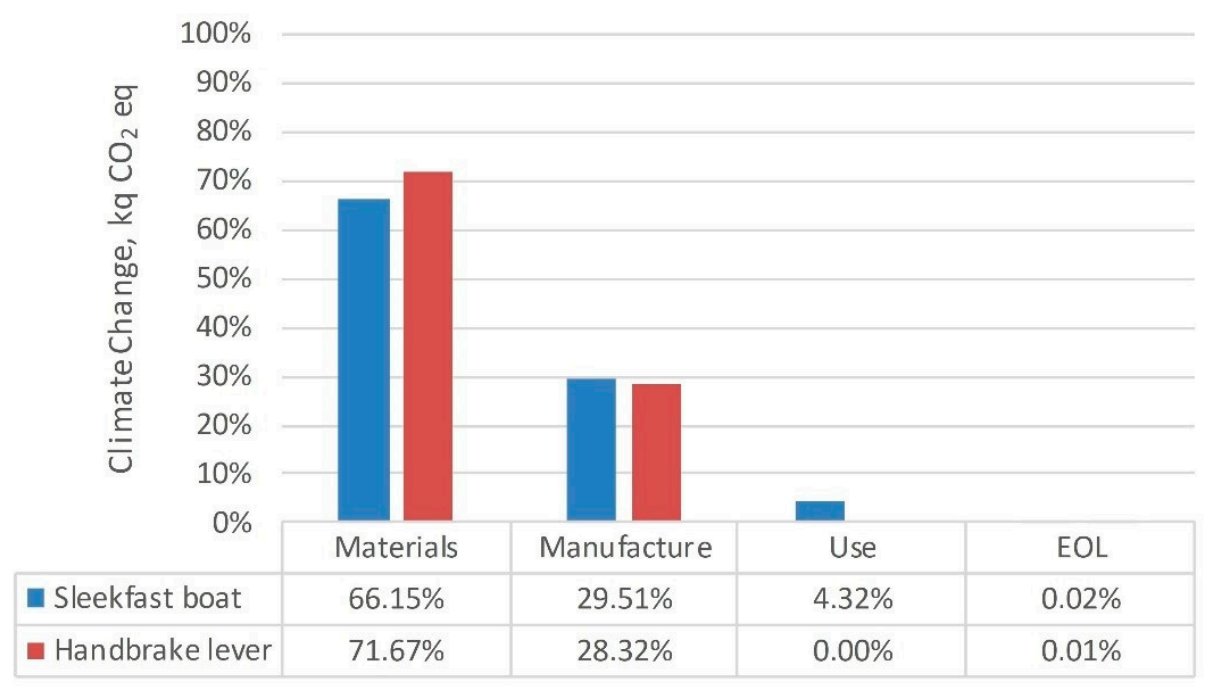

Figure 5. Percent contribution of life cycle stages to the total impact for the two case studies: composite Sleekfast sailing boat and handbrake lever. 
As Figure 6 shows for both cases, 'materials' is the most relevant life cycle stage across impact categories, accounting for $47-72 \%$ of the life cycle impacts for the case of the Sleekfast boat and $60-90 \%$ for the case of the handbrake lever. The main contributing factors within the 'materials' life cycle stage are presented in Figure 5. For the Sleekfast boat, CF is consistently an environmental hotspot, accounting for $32-71 \%$ of the 'materials' impact. For the handbrake lever, CNTs are also a hotspot and, for some impact categories, such as the ones related to toxicity, the contribution of CNT is higher than that of CF. Detailed accounts of the contribution of each inventory aspect to each impact category are given in Tables A3 and A4 in Appendix A.

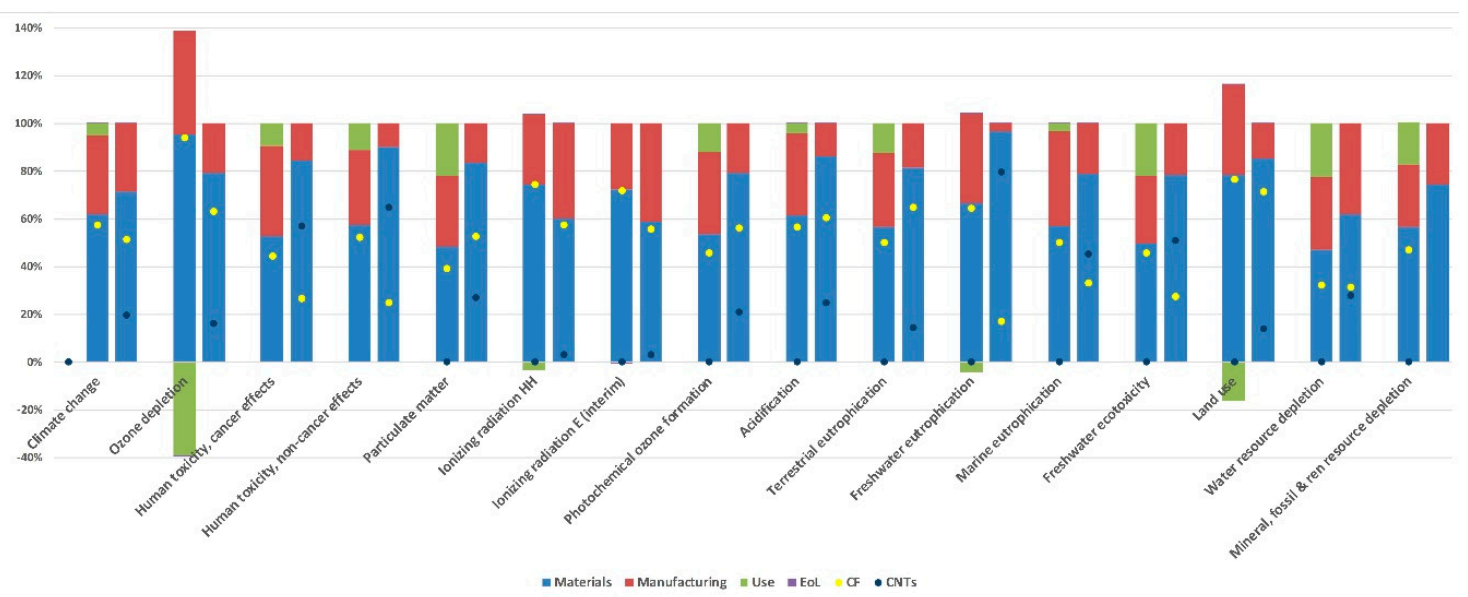

Figure 6. Percent contribution of the life cycle stages and of the main raw materials for the two studied cases. CNT, carbon nanotube.

Focusing on the two main impact contributors, CFs are manufactured from a polymeric feedstock, the "precursor", which in majority is derived from polyacrylonitrile (PAN). Precursor formulation (polymerization) begins with an acrylonitrile monomer, which is combined in a reactor with plasticized acrylic co-monomers and a catalyst (sulfuric acid). As Figure 7 indicates for climate change, $\mathrm{CF}$ production is a highly energy-intensive process $(E=368 \mathrm{MJ} / \mathrm{kg} \mathrm{CF})$, with electricity accounting for $85 \%$ on climate change impact and PAN precursor for $15 \%$ (for the production of $1 \mathrm{~kg}$ PAN precursor, acrylonitrile has the major contribution, $53 \%$ over $47 \%$ of electricity, on climate change impact). As for CNTs, the electricity requirements for their production are also the major hotspot [97].

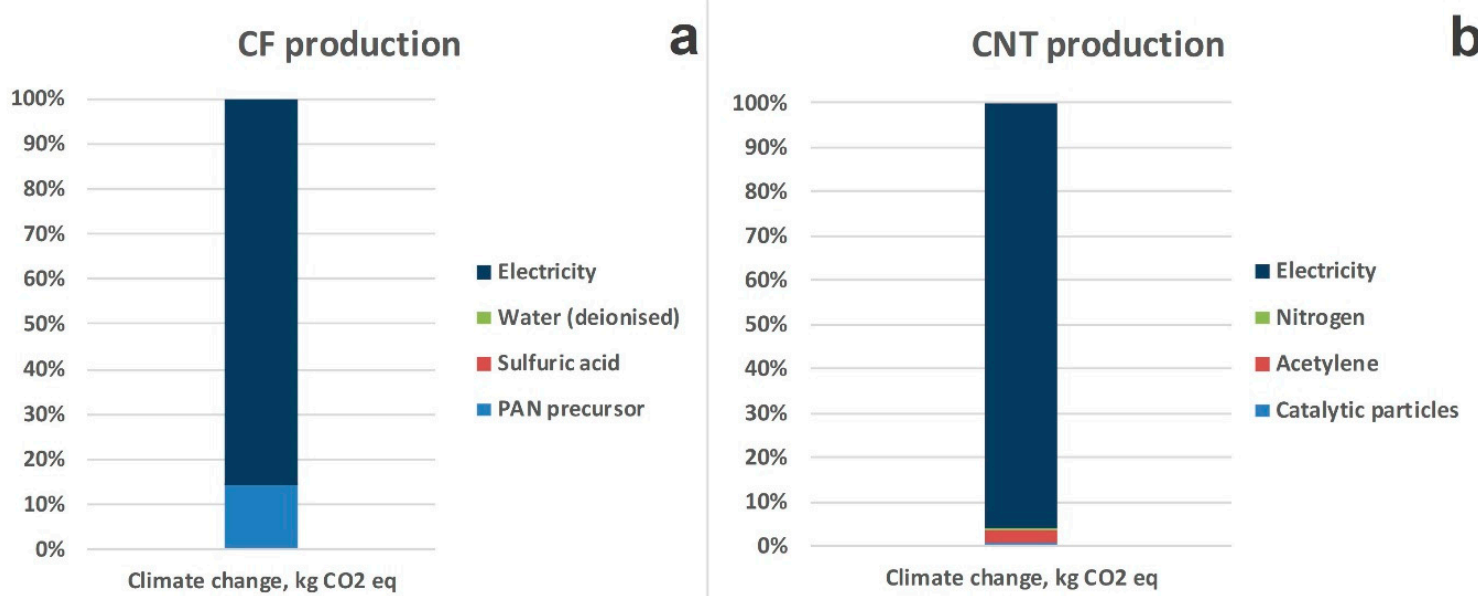

Figure 7. Percent contribution of CF (a) and CNT (b) production on climate change impact category. PAN, polyacrylonitrile. 
As the productions of carbon fibres and CNTs are energy intensive processes, the GHG emissions highly depend on the electricity grid source. Indicatively, the $\mathrm{CO}_{2}$ intensity of electricity generation in EU-27 is $0.295 \mathrm{gCO}_{2} / \mathrm{kWh}$ [98], and in Japan, it is $0.496 \mathrm{~g} \mathrm{CO}_{2} / \mathrm{kWh}$ [99]. This is expected as the Japanese grid has a renewable energy share of $16 \%$ [100], while the share in EU-27 is $29 \%$ [101]. Aside from climate change, electricity generation gives rise to negative impacts on the environment and human health throughout all life cycle stages.

\section{End of Life-The Most Uncertain Life Cycle Stage with the Highest Potential for Improvement}

Given the domination of materials in the overall impacts, their treatment and recycling at the EoL of the plants is consequently important as it could lead to environmental savings due to the avoided production of raw materials (recycled carbon fibres) through system expansion (Figure 8). The results of the scenario analysis for the different EoL pathways indicated that the savings from pyrolysis can contribute up to $40 \%$ in the total impact. The results, aligned with other literature, signify the potential environmental improvements due to recovery and recycling.

\section{Alternative EOL scenarios diff. \% from Landfill (Ref)}

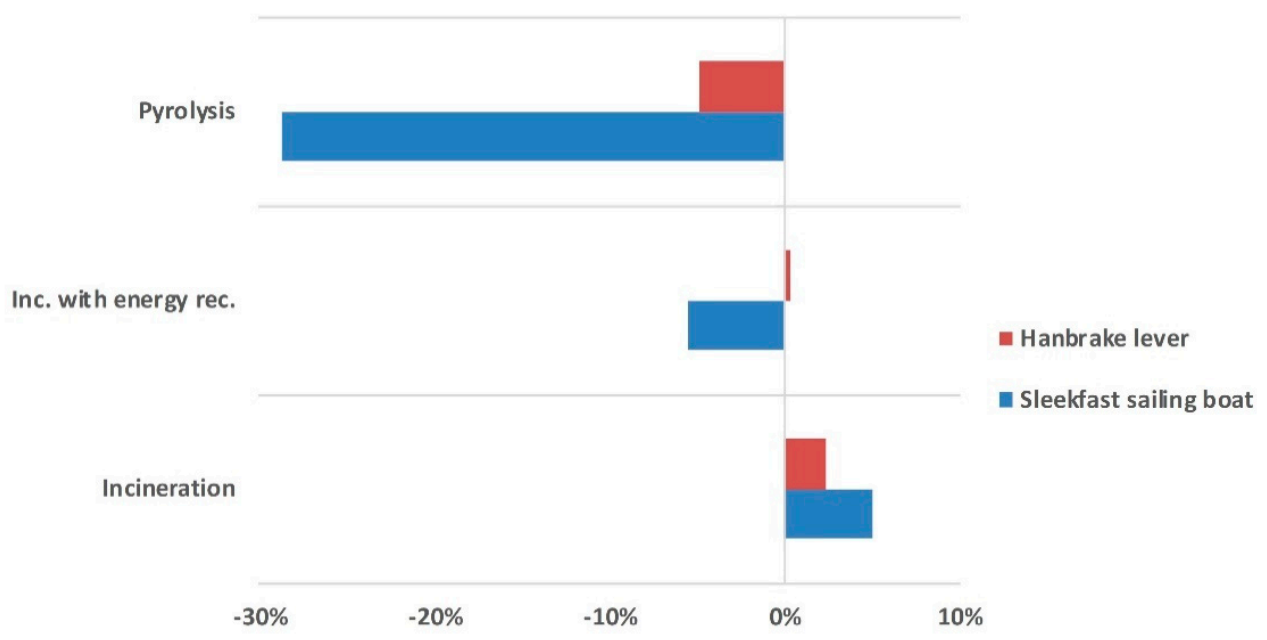

Figure 8. Percentage difference in climate change impact of the alternative EOL scenarios compared with the reference.

\section{Discussion}

Salt and corrosive water can cause severe damages to watercrafts over time, while thermoset composites could be an attractive substitute over the predominantly used materials (GRP) thanks to their strong resistance in corrosion and fatigue, also minimizing the maintenance requirements [102]. The wide development of reinforced epoxies in the last decades can offer significant performance and quality improvements to the boat as a result of higher elongation, tensile strength, and modulus over polyester (PE) and vinyl ester (VE) resins; CFRP use in marine applications in turn gives technical advantages to shipbuilders. Reduced weight is achieved by increasing the fibre content while decreasing the number of layers without compromising the mechanical behaviour of the hull, thus providing higher speed and less fuel consumption. In addition, because of the high value of $C F$, research has continued to focus on improving recyclability to recover CF from CFRPs via thermal and chemical techniques [31]. Despite the fact that is a domain rapidly advancing and that carbon fibre/epoxy composites are increased providing materials in many industries (automotive, manufacturing, aerospace), the enormous generation of CFRP wastes within few years remains an unsolved problem. Recently, several recycling pathways of carbon fibres are reaching a mature phase, as recovered CF from waste can be achieved at one order of magnitude ( $€ 5 / \mathrm{kg}$, [25]) less than virgin $\mathrm{CF}$ cost; $\mathrm{VCF}$ prices are estimated at $€ 30-60 / \mathrm{kg}$, [103]. The energy required to recycle $\mathrm{CF}$ via pyrolysis 
is $5-10 \%$ less compared with the energy for virgin CF production (13-32 MJ/kg and 183-286 MJ/kg, respectively) [104]. Additionally, initiatives from large aerospace companies (e.g., Airbus) promote environmental responsibility across the entire lifecycle of an aircraft. The cost savings of recycled fibres can generally be $20-40 \%$ [49]. This constitutes recycled carbon fibres as tentative substitutes of glass fibre or virgin carbon fibre in applications with comparable mechanical properties.

CFRP recycling and the reuse of the recovered CF in composite materials (e.g., Figure 9) offer low production impacts associated with the virgin $\mathrm{CF}$ substitution, while the respective low cost could open up new composites markets-for example, in the automotive sector [96]. While the direct life cycle environmental impact of a composite is dependent on the design criteria of the components, recycled CF components can provide low production impacts relative to lightweight competitor materials (e.g., aluminium, virgin CFRP) [25].

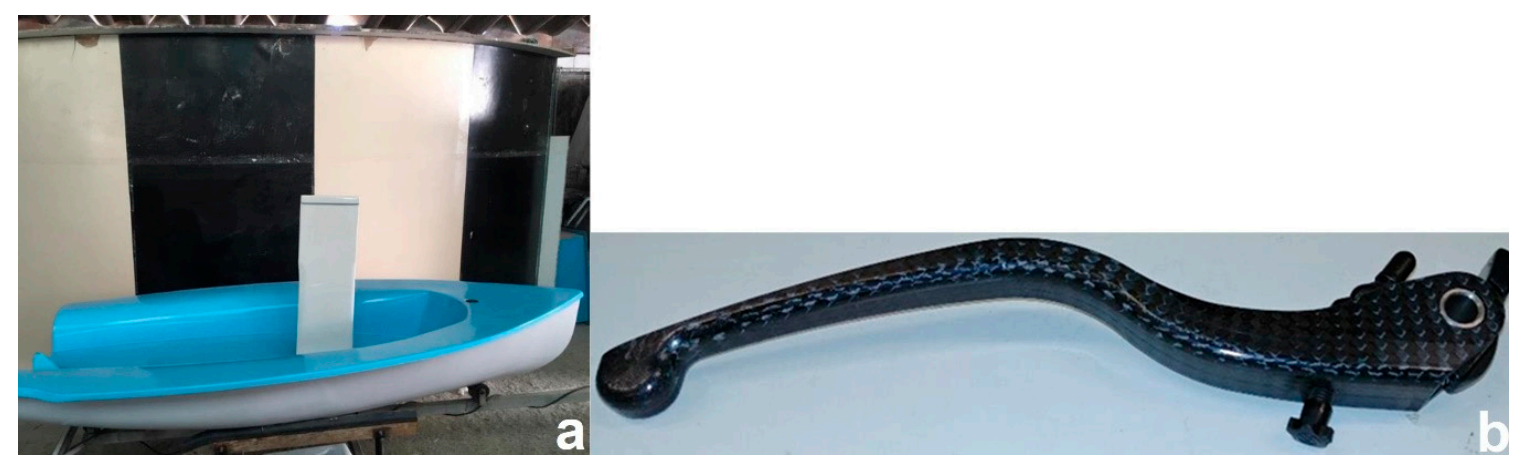

Figure 9. MODCOMP project advanced material prototypes: (a) sailing boat; (b) lever.

Vo Dong et al. [76] performed an economical and environmental assessment on the recovery and disposal pathways for CFRP waste management and indicated that the carbon fibre recycling cannot currently compete in cost with the conventional landfill and incineration routes. It was estimated that disposal of CFRP waste would require approximately $0.1 € / \mathrm{kg}$, without accounting profits from recoverable products in waste. Thus, recycling of carbon fibres needs to reduce further the unit cost to be comparable with current non-recover pathways. To conclude, fibre recovery rate and recycling capacity are pivotal to decrease the unit cost of recycled fibre as well as GWP impacts.

Even if LCA is considered a holistic, comprehensive methodology for environmental impact assessments, it still lacks the capacity to assess the impact of nanomaterials and nano-enabled products. Despite the efforts $[105,106]$, the potential impacts of the released NMs to human and environmental health have not been covered yet, while several uncertainties and data gaps exist $[107,108]$. Another issue is that nanomaterials, which are increasing in number in several everyday applications the last decade, are entering into waste streams as part of end-of-life products along with conventional waste, without any real understanding of their environmental impacts or health risks on human beings and living organisms [109]. Moreover, concerning the EoL of NMs, there are only few studies that have investigated the presence of NMs' emissions in municipal solid waste (MSW) incineration. For instance, in the case of CNTs, there are contradictory findings; from an efficiency burn at approximately $94 \%$, as a result of their chemical nature, to the opposite scenario of a non-efficient incineration. Thus, further investigation into the different NMs types and treatment routes is required [109].

\section{Conclusions}

In the present study, the environmental impacts over the entire life cycle of two carbon fibre/epoxy composite prototypes were assessed, assuming four end-of-life treatments for CFRP waste to be hypothetically performed; namely, (a) landfill, (b) incineration of hazardous waste, (c) incineration with energy recovery, and (d) thermal recycling via pyrolysis. The former technology has been set as the reference scenario with which to be compared. The functional unit was 1 piece of carbon fibre/epoxy composite prototypes. The results of this work have indicated that there are potential benefits from 
recycling of CFRP waste that are strongly associated with the environmental impacts of the materials. These include the following:

1. 'Materials' contribution dominates in the calculated 14 impact categories, with CF and CNTs being the environmental hotspots, both thanks to the high energy intensive production process. The laboratory production of CNTs required $1104 \mathrm{MJ} / \mathrm{kg}$ CNTs. While the upscale of CNT manufacturing becomes more mature reaching the industrial-scale, a reduction of approximately two to three orders of magnitude in manufacturing energy intensity can be expected [110].

2. Recycling via pyrolysis can lead to significant impact savings due to material recovery (up to $40 \%$ for the case of Sleekfast boat).

3. Incineration with energy recovery also leads to environmental savings, but much lower than recycling ( $\sim 7$ and $\sim 4$ times lower for the boat and the lever cases, respectively).

4. Incineration without energy recovery contributes negatively by approximately $5 \%$ and $2 \%$ to climate change for the boat and lever, respectively. It is worth mentioning that this option accounts for around $1-2 \%$ of total municipal waste treated inside and outside Europe [111].

The use of the LCA tool provided insights into the environmental performance of processes across the life cycle stage of a CFRP product, allowing for product developers to set the focus right on future environmental improvements and eco-design of novel carbon fibre-based materials. The results showcased that carbon fibre and CNTs production are energy-intensive processes and the main contributors to climate change. Thus, energy efficiency measures and cleaner electricity grid mixes can have a significant influence on the environmental performance. Aligning with other literature, the study also showed that research efforts should focus on improving recycling technologies to recover high quality CF from CFRP waste and reuse them in manufacturing high performance materials, ideally of equal virgin CFRP performance.

Author Contributions: Conceptualization, E.P.K., F.P., A.G., A.B., and P.K.; Methodology, E.P.K., F.P., A.G, A.B., and P.K.; Investigation F.P., A.G., P.K., A.B., E.P.K., A.-F.T., D.S., C.A.C., N.R., R.M.S., G.S., G.M., G.V. G.G.; Writing-original draft preparation, all; Writing—review and editing, E.P.K., F.P., and A.G. All authors have read and agreed to the published version of the manuscript.

Funding: This research was funded by European Union's Horizon 2020 Research and Innovation Programme MODCOMP project under grant number 685844.

Conflicts of Interest: The authors declare no conflict of interest.

\section{Appendix A}

Table A1. Life cycle inventory (LCI) of 1-piece $(0.15 \mathrm{~kg})$ handbrake lever.

\begin{tabular}{ccc}
\hline & MATERIALS & \\
\hline Input (materials, energy, etc.) & Unit & Comment \\
Carbon fibre & $0.12 \mathrm{~kg}$ & [70] (updated 2014) \\
Epoxy resin \{GLO\} & $0.02 \mathrm{~kg}$ & Ecoinvent 3.3 \\
CNTs & $0.01 \mathrm{~kg}$ & Experimental Data \\
Electricity, medium voltage $\{\mathrm{GR}\}$ & $11.04 \mathrm{MJ}$ & CNT production energy, \\
Electricity, medium voltage $\{J P\}$ & $45.631 \mathrm{MJ}$ & CFperimental Data \\
Output/Emissions to air & Unit & Coduction energy [70,112] \\
Ammonia & $0.0001 \mathrm{~kg}$ & [70] (updated 2014) \\
Hydrogen cyanide & $0.0019 \mathrm{~kg}$ & [70] (updated 2014) \\
Carbon monoxide & $0.0004 \mathrm{~kg}$ & [70] (updated 2014) \\
Carbon dioxide & $0.1216 \mathrm{~kg}$ & [70] (updated 2014) \\
Ethane & $1.2 \times 10^{-6} \mathrm{~kg}$ & [70] (updated 2014) \\
Acrylonitrile & $0.0026 \mathrm{~kg}$ & [70] (updated 2014) \\
\hline
\end{tabular}


Table A1. Cont.

\begin{tabular}{|c|c|c|}
\hline Nitrogen & $0.2144 \mathrm{~kg}$ & Experimental Data \\
\hline VOC, volatile organic compounds & $0.0053 \mathrm{~kg}$ & Experimental Data \\
\hline Soot & $0.0013 \mathrm{~kg}$ & Experimental Data \\
\hline Ethyne & $0.0073 \mathrm{~kg}$ & Experimental Data \\
\hline Output/Emissions to water & Unit & Comment \\
\hline Sulfuric acid & $0.0024 \mathrm{~kg}$ & [70] (updated 2014) \\
\hline N-N-Dimethylformamide & $0.0021 \mathrm{~kg}$ & [70] (updated 2014) \\
\hline PAH, polycyclic aromatic hydrocarbons & $6.6 \times 10^{-5} \mathrm{~kg}$ & Experimental Data \\
\hline \multicolumn{3}{|c|}{ MANUFACTURE } \\
\hline Input (materials, energy, etc.) & Unit & Comment \\
\hline Production scrap & $0.02 \mathrm{pc}$ & Assumed $2 \%$ production scrap \\
\hline Packaging materials & $1.272 \mathrm{~kg}$ & Experimental Data \\
\hline Electricity, medium voltage $\{$ EU-27\} & $18 \mathrm{MJ}$ & Experimental Data \\
\hline \multicolumn{3}{|c|}{ EOL DISPOSAL } \\
\hline Scenario 1: Landfill & Unit & Comment \\
\hline Inert waste & $0.15 \mathrm{~kg}$ & {$[75]$} \\
\hline Electricity, medium voltage $\{$ EU-27\} & $0.0405 \mathrm{MJ}$ & Industrial shredder energy [55] \\
\hline Scenario 2: Incineration of Hazardous waste & Unit & Comment \\
\hline Electricity, medium voltage $\{$ EU-27\} & $0.0405 \mathrm{MJ}$ & Industrial shredder [55] \\
\hline $\begin{array}{c}\text { Scenario 3: MSW incineration with energy } \\
\text { recovery }\end{array}$ & Unit & Comment \\
\hline Electricity, medium voltage $\{$ EU-27\} & $0.0405 \mathrm{MJ}$ & Industrial shredder [55] \\
\hline Output/ avoided products & Unit & Comment \\
\hline Electricity, medium voltage $\{$ EU-27 $\}$ & $1.68 \mathrm{MJ}$ & $35 \%$ efficiency [112] \\
\hline $\begin{array}{l}\text { Heat, for reuse in municipal waste incineration } \\
\qquad\{\text { EU-27\} }\end{array}$ & $4.8 \mathrm{MJ}$ & {$[81][75]$} \\
\hline Scenario 4: Thermal recycling via pyrolysis & Unit & Comment \\
\hline Electricity, medium voltage $\{$ EU-27 $\}$ & $0.0405 \mathrm{MJ}$ & Industrial shredder [55] \\
\hline Electricity, medium voltage $\{$ EU-27\} & $4.5 \mathrm{MJ}$ & {$[61]$} \\
\hline Output/ avoided products & Unit & Comment \\
\hline Carbon fibre & $0.0612 \mathrm{~kg}$ & $60 \%$ CF recovery $[78]$ \\
\hline Electricity, medium voltage $\{$ EU-27\} & $5.94 \mathrm{MJ}$ & {$[77]$} \\
\hline
\end{tabular}

Table A2. LCI of 1-piece (26 kg) 'Sleekfast' sailing boat.

\begin{tabular}{ccc}
\hline & MATERIALS & \\
\hline Input (materials, energy) & Unit & Comment \\
Carbon fibre & $10.5 \mathrm{~kg}$ & [70] (updated 2014) \\
SICOMIN 1500 (0,06 wt $\%$ MWCNTs) & $10 \mathrm{~kg}$ & Experimental Data \\
PVC foam & $1.5 \mathrm{~kg}$ & Ecoinvent 3.4 \\
Epoxy gelcoat & $4 \mathrm{~kg}$ & EuCIA - EcoImpact Calculator report \\
Electricity, medium voltage $\{\mathrm{JP}\}$ & $3680 \mathrm{MJ}$ & v1.3, Ecoinvent 3.4 \\
Electricity, medium voltage $\{$ EU-27\} & $6.48 \mathrm{MJ}$ & CF production energy [70,112] \\
Electricity, medium voltage $\{$ PT $\}$ & $600 \mathrm{MJ}$ & Experimental Data \\
Output/Emissions to air & Unit & Experimental Data \\
Ammonia & $0.0122 \mathrm{~kg}$ & Comment \\
Hydrogen cyanide & $0.1649 \mathrm{~kg}$ & [70] (updated 2014) \\
Carbon monoxide & $0.0340 \mathrm{~kg}$ & [70] (updated 2014) \\
Carbon dioxide & $10.636 \mathrm{~kg}$ & [70] (updated 2014) \\
Ethane & $0.0001 \mathrm{~kg}$ & [70] (updated 2014) \\
Acrylonitrile & $0.2243 \mathrm{~kg}$ & [70] (updated 2014) \\
Nitrogen & $0.1415 \mathrm{~kg}$ & Experimental Data \\
VOC, volatile organic compounds & $0.0035 \mathrm{~kg}$ & Experimental Data \\
\hline
\end{tabular}


Table A2. Cont.

\begin{tabular}{|c|c|c|}
\hline Soot & $0.0009 \mathrm{~kg}$ & Experimental Data \\
\hline Ethyne & $0.0048 \mathrm{~kg}$ & Experimental Data \\
\hline VOC, volatile organic compounds & $0.0196 \mathrm{~kg}$ & Experimental Data \\
\hline Carbon dioxide & $3.040 \mathrm{~kg}$ & Experimental Data \\
\hline Output/Emissions to water & Unit & Comment \\
\hline Sulfuric acid & $0.2089 \mathrm{~kg}$ & [70] (updated 2014) \\
\hline N-N-Dimethylformamide & $0.1857 \mathrm{~kg}$ & [70] (updated 2014) \\
\hline PAH, polycyclic aromatic hydrocarbons & $4.4 \times 10^{-5} \mathrm{~kg}$ & Experimental Data \\
\hline \multicolumn{3}{|c|}{ MANUFACTURE } \\
\hline Input (materials, energy) & Unit & Comment \\
\hline Production scrap & $1.47 \mathrm{~kg}$ & Experimental Data \\
\hline $\begin{array}{l}\text { Packaging film, low density polyethylene } \\
\qquad\{\mathrm{GLO}\}\end{array}$ & $0.35 \mathrm{~kg}$ & Experimental Data \\
\hline Acetone, liquid $\{\mathrm{GLO}\}$ & $2.37 \mathrm{~kg}$ & Experimental Data \\
\hline Electricity, medium voltage $\{\mathrm{PT}\}$ & $230.4 \mathrm{MJ}$ & Experimental Data \\
\hline \multicolumn{3}{|c|}{ USE } \\
\hline Epoxy gelcoat & $30 \mathrm{~kg}$ & $\begin{array}{l}\text { Assumed } 2 \mathrm{~kg} \text { biannually for } 30 \text { years } \\
\text { operational life (EuCIA - EcoImpact } \\
\text { Calculator report v1.3, Ecoinvent } 3.4 \text { ) }\end{array}$ \\
\hline \multicolumn{3}{|c|}{ EOL DISPOSAL } \\
\hline Scenario 1: Landfill & Unit & Comment \\
\hline Inert waste & $26 \mathrm{~kg}$ & {$[75]$} \\
\hline Electricity, medium voltage $\{$ EU-27\} & $7.02 \mathrm{MJ}$ & Industrial shredder energy [55] \\
\hline $\begin{array}{c}\text { Scenario 2: Incineration of Hazardous } \\
\text { waste }\end{array}$ & Unit & Comment \\
\hline Electricity, medium voltage $\{$ EU-27\} & $7.02 \mathrm{MJ}$ & $\begin{array}{c}\text { Industrial shredder [55], Incineration } \\
\text { Haz. (Ecoinvent) }\end{array}$ \\
\hline $\begin{array}{l}\text { Scenario 3: MSW incineration with energy } \\
\text { recovery }\end{array}$ & Unit & Comment \\
\hline Electricity, medium voltage $\{$ EU-27\} & $7.02 \mathrm{MJ}$ & Industrial shredder [55] \\
\hline Output/ avoided products & Unit & Comment \\
\hline Electricity, medium voltage $\{$ EU-27\} & 291 MJ & $35 \%$ efficiency \\
\hline $\begin{array}{l}\text { Heat, for reuse in municipal waste } \\
\text { incineration }\{E U-27\}\end{array}$ & $832 \mathrm{MJ}$ & {$[75,81]$} \\
\hline Scenario 4: Thermal recycling via pyrolysis & Unit & Comment \\
\hline Electricity, medium voltage $\{$ EU-27\} & $7.02 \mathrm{MJ}$ & Industrial shredder [55] \\
\hline Electricity, medium voltage $\{$ EU-27\} & $780 \mathrm{MJ}$ & {$[61]$} \\
\hline Output/ avoided products & Unit & Comment \\
\hline Carbon fibre & $6.3 \mathrm{~kg}$ & $60 \%$ CF recovery [78] \\
\hline Electricity, medium voltage $\{$ EU-27\} & $396 \mathrm{MJ}$ & {$[77]$} \\
\hline
\end{tabular}

Table A3. Percentage contribution of each inventory aspect to each impact category for the Sleekfast sailing boat.

\begin{tabular}{ccccccc}
\hline Impact Category & Unit & Materials & Manufacturing & Use & EoL & $\begin{array}{c}\text { CF in } \\
\text { Materials }\end{array}$ \\
\hline Climate change & kg CO 2 eq & $62 \%$ & $33 \%$ & $5 \%$ & $0 \%$ & $57 \%$ \\
Ozone depletion & kg CFC-11 eq & $54 \%$ & $24 \%$ & $22 \%$ & $0 \%$ & $53 \%$ \\
Human toxicity, cancer effects & CTUh & $53 \%$ & $38 \%$ & $9 \%$ & $0 \%$ & $44 \%$ \\
Human toxicity, non-cancer & CTUh & $57 \%$ & $31 \%$ & $11 \%$ & $0 \%$ & $52 \%$ \\
effects & kg PM2.5 eq & $48 \%$ & $30 \%$ & $22 \%$ & $0 \%$ & $39 \%$ \\
Particulate matter & kBq U235 eq & $70 \%$ & $27 \%$ & $3 \%$ & $0 \%$ & $69 \%$ \\
Ionizing radiation HH & CTUe & $72 \%$ & $28 \%$ & $0 \%$ & $0 \%$ & $71 \%$ \\
Ionizing radiation E (interim) & kg NMVOC eq & $53 \%$ & $34 \%$ & $12 \%$ & $0 \%$ & $45 \%$ \\
Photochemical ozone & & & & & & \\
formation & & &
\end{tabular}


Table A3. Cont.

\begin{tabular}{ccccccc}
\hline Impact Category & Unit & Materials & Manufacturing & Use & EoL & $\begin{array}{c}\text { CF in } \\
\text { Materials }\end{array}$ \\
\hline Acidification & molc H+ eq & $62 \%$ & $34 \%$ & $4 \%$ & $0 \%$ & $57 \%$ \\
Terrestrial eutrophication & molc N eq & $56 \%$ & $31 \%$ & $13 \%$ & $0 \%$ & $50 \%$ \\
Freshwater eutrophication & kg P eq & $62 \%$ & $35 \%$ & $4 \%$ & $0 \%$ & $59 \%$ \\
Marine eutrophication & kg N eq & $57 \%$ & $40 \%$ & $3 \%$ & $0 \%$ & $50 \%$ \\
Freshwater ecotoxicity & CTUe & $50 \%$ & $28 \%$ & $22 \%$ & $0 \%$ & $46 \%$ \\
Land use & kg C deficit & $59 \%$ & $29 \%$ & $12 \%$ & $0 \%$ & $57 \%$ \\
Water resource depletion & m water eq & $47 \%$ & $30 \%$ & $23 \%$ & $0 \%$ & $32 \%$ \\
Mineral, fossil, and ren & kg Sb eq & $56 \%$ & $26 \%$ & $17 \%$ & $0 \%$ & $46 \%$ \\
resource depletion & & & & &
\end{tabular}

Table A4. Percentage contribution of each inventory aspect to each impact category for the handbrake lever.

\begin{tabular}{cccccc}
\hline Impact Category & Unit & Materials & Manufacturing & EoL & $\begin{array}{c}\text { CF in } \\
\text { Materials }\end{array}$ \\
\hline Climate change & kg CO 2 eq & $72 \%$ & $28 \%$ & $0 \%$ & $51 \%$ \\
Ozone depletion & kg CFC-11 eq & $79 \%$ & $21 \%$ & $0 \%$ & $63 \%$ \\
Human toxicity, cancer effects & CTUh & $84 \%$ & $16 \%$ & $0 \%$ & $27 \%$ \\
Human toxicity, non-cancer effects & CTUh & $90 \%$ & $10 \%$ & $0 \%$ & $25 \%$ \\
Particulate matter & kg PM2.5 eq & $83 \%$ & $17 \%$ & $0 \%$ & $53 \%$ \\
Ionizing radiation HH & kB U235 eq & $60 \%$ & $40 \%$ & $0 \%$ & $57 \%$ \\
Ionizing radiation E (interim) & CTUe & $59 \%$ & $41 \%$ & $0 \%$ & $56 \%$ \\
Photochemical ozone formation & kg NMVOC eq & $79 \%$ & $21 \%$ & $0 \%$ & $56 \%$ \\
Acidification & molc H+ eq & $86 \%$ & $14 \%$ & $0 \%$ & $60 \%$ \\
Terrestrial eutrophication & molc N eq & $82 \%$ & $18 \%$ & $0 \%$ & $65 \%$ \\
Freshwater eutrophication & kg P eq & $97 \%$ & $3 \%$ & $0 \%$ & $17 \%$ \\
Marine eutrophication & kg N eq & $79 \%$ & $21 \%$ & $0 \%$ & $33 \%$ \\
Freshwater ecotoxicity & CTUe & $79 \%$ & $21 \%$ & $0 \%$ & $28 \%$ \\
Land use & kg C deficit & $85 \%$ & $15 \%$ & $0 \%$ & $71 \%$ \\
Water resource depletion & m 3 water eq & $62 \%$ & $38 \%$ & $0 \%$ & $31 \%$ \\
Mineral, fossil, and ren resource & kg Sb eq & $74 \%$ & $26 \%$ & $0 \%$ & $60 \%$ \\
depletion & & & & & \\
\hline
\end{tabular}

\section{References}

1. Koumoulos, E.P.; Trompeta, A.-F.; Santos, R.-M.; Martins, M.; Santos, C.M.; Iglesias, V.; Böhm, R.; Gong, G.; Chiminelli, A.; Verpoest, I.; et al. Research and Development in Carbon Fibers and Advanced High-Performance Composites Supply Chain in Europe: A Roadmap for Challenges and the Industrial Uptake. J. Compos. Sci. 2019, 3, 86. [CrossRef]

2. Roy, M.; Tran, P.; Dickens, T.; Schrand, A. Composite Reinforcement Architectures: A Review of Field-Assisted Additive Manufacturing for Polymers. J. Compos. Sci. 2019, 4, 1. [CrossRef]

3. Sahu, P.; Sharma, N.; Panda, S.K. Numerical prediction and experimental validation of free vibration responses of hybrid composite (Glass/Carbon/Kevlar) curved panel structure. Compos. Struct. 2020, 241, 112073. [CrossRef]

4. Fausey, C.L.; Zucker, I.; Lee, D.E.; Shaulsky, E.; Zimmerman, J.B.; Elimelech, M. Tunable Molybdenum Disulfide-Enabled Fiber Mats for High-Efficiency Removal of Mercury from Water. ACS Appl. Mater. Interfaces 2020, 12, 18446-18456. [CrossRef]

5. Johnson, S.; Faradilla, R.H.F.; Venditti, R.A.; Lucia, L.; Hakovirta, M. Hydrothermal Carbonization of Nanofibrillated Cellulose: A Pioneering Model Study Demonstrating the Effect of Size on Final Material Qualities. ACS Sustain. Chem. Eng. 2020, 8, 1823-1830. [CrossRef] 
6. Li, S.; Lv, R.; Wu, Y.; Huang, F.; Zhang, X.; Yue, T. Size-, Aggregation-, and Oxidization-Dependent Perturbation of Methane Hydrate by Graphene Nanosheets Revealed by Molecular Dynamics Simulations. J. Phys. Chem. C 2019, 123, 13154-13166. [CrossRef]

7. Afreen, S.; Omar, R.A.; Talreja, N.; Chauhan, D.; Ashfaq, M. Carbon-Based Nanostructured Materials for Energy and Environmental Remediation Applications; Springer: Cham, Switzerland, 2018; pp. 369-392.

8. Koniuszewska, A.G.; Kaczmar, J.W. Application of Polymer Based Composite Materials in Transportation. Prog. Rubber Plast. Recycl. Technol. 2016, 32, 1-24. [CrossRef]

9. Bacakova, L.; Pajorova, J.; Tomkova, M.; Matejka, R.; Broz, A.; Stepanovska, J.; Prazak, S.; Skogberg, A.; Siljander, S.; Kallio, P. Applications of Nanocellulose/Nanocarbon Composites: Focus on Biotechnology and Medicine. Nanomaterials 2020, 10, 196. [CrossRef] [PubMed]

10. Tian, H.; Wang, X.; Wang, L.; Yu, J.; Zhang, Q.; Chen, R.; Yan, Y.; Sun, D. Graphene-Based Antibacterial Films with Enhanced Mechanical Properties. Integr. Ferroelectr. 2020, 206, 79-86. [CrossRef]

11. Rajakumar, G.; Zhang, X.-H.; Gomathi, T.; Wang, S.-F.; Azam Ansari, M.; Mydhili, G.; Nirmala, G.; Alzohairy, M.A.; Chung, I.-M. Current Use of Carbon-Based Materials for Biomedical Applications-A Prospective and Review. Processes 2020, 8, 355. [CrossRef]

12. Siwal, S.S.; Zhang, Q.; Devi, N.; Thakur, V.K. Carbon-Based Polymer Nanocomposite for High-Performance Energy Storage Applications. Polymers 2020, 12, 505. [CrossRef] [PubMed]

13. Chakraborty, P.; Ma, T.; Zahiri, A.H.; Cao, L.; Wang, Y. Carbon-Based Materials for Thermoelectrics. Adv. Condens. Matter Phys. 2018, 2018, 3898479. [CrossRef]

14. Yıldırım, G.; Öztürk, O.; Al-Dahawi, A.; Afşın Ulu, A.; Şahmaran, M. Self-sensing capability of Engineered Cementitious Composites: Effects of aging and loading conditions. Constr. Build. Mater. 2020, 231, 117132. [CrossRef]

15. Trompeta, A.-F.; Koumoulos, E.; Stavropoulos, S.; Velmachos, T.; Psarras, G.; Charitidis, C. Assessing the Critical Multifunctionality Threshold for Optimal Electrical, Thermal, and Nanomechanical Properties of Carbon Nanotubes/Epoxy Nanocomposites for Aerospace Applications. Aerospace 2019, 6, 7. [CrossRef]

16. Karnati, S.R.; Agbo, P.; Zhang, L. Applications of silica nanoparticles in glass/carbon fiber-reinforced epoxy nanocomposite. Compos. Commun. 2020, 17, 32-41. [CrossRef]

17. Hu, Y.; Shi, Y.; Liu, D.; Guo, J.; Zhang, J.; Chen, Z. Damage tolerance of 2-dimentional UHMWPE/CF hybrid woven laminates subjected to low-velocity impact. Mater. Des. 2020, 191, 108604. [CrossRef]

18. Aly, N.M. A review on utilization of textile composites in transportation towards sustainability. IOP Conf. Ser. Mater. Sci. Eng. 2017, 254, 42002. [CrossRef]

19. Fekete, J.R.; Hall, J.N. 1-Design of Auto Body: Materials Perspective; Rana, R., Singh, S.B.B.T.-A.S., Eds.; Woodhead Publishing: Sawston, UK, 2017; pp. 1-18. ISBN 978-0-08-100638-2.

20. Composites Market Report. 2018. Available online: https://www.avk-tv.de/files/20181115_avk_ccev_market_ report_2018_final.pdf (accessed on 22 January 2019).

21. Karuppannan Gopalraj, S.; Kärki, T. A review on the recycling of waste carbon fibre/glass fibre-reinforced composites: Fibre recovery, properties and life-cycle analysis. SN Appl. Sci. 2020, 2, 433. [CrossRef]

22. Hussain, C.M.; Mishra, A.K. Major Environmental Issues and New Materials. In New Polymer Nanocomposites for Environmental Remediation; Hussain, C.M., Mishra, A.K., Eds.; Elsevier: Amsterdam, The Netherlands, 2018; pp. 77-97.

23. Murphy, T. The New Face of CAFE. Ward's AutoWorld. 2008. Available online: http://wardsautoworld.com/ ar/auto_new_face_cafe/ (accessed on 22 January 2019).

24. Meng, F.; Olivetti, E.A.; Zhao, Y.; Chang, J.C.; Pickering, S.J.; McKechnie, J. Comparing Life Cycle Energy and Global Warming Potential of Carbon Fiber Composite Recycling Technologies and Waste Management Options. ACS Sustain. Chem. Eng. 2018, 6, 9854-9865. [CrossRef]

25. Meng, F.; Mckechnie, J.; Turner, T.A.; Pickering, S.j. Energy and environmental assessment and reuse of fluidised bed recycled carbon fibres. Compos. Part A Appl. Sci. Manuf. 2017, 100, 206-214. [CrossRef]

26. Duflou, J.; Deng, Y.; Van Acker, K.; Dewulf, W. Do fiber-reinforced polymer composites provide environmentally benign alternatives? A life-cycle-assessment-based study. MRS Bull. 2012, 37, 374-382. [CrossRef]

27. Das, S. Life cycle assessment of carbon fiber-reinforced polymer composites. Int. J. Life Cycle Assess. 2011, 16, 268-282. [CrossRef] 
28. Semitekolos, D.; Trompeta, A.-F.; Husarova, I.; Man'ko, T.; Potapov, A.; Romenskaya, O.; Liang, Y.; Li, X.; Giorcelli, M.; Dong, H.; et al. Comparative Physical-Mechanical Properties Assessment of Tailored Surface-Treated Carbon Fibres. Materials 2020, 13, 3136. [CrossRef] [PubMed]

29. Liang, Y.; Li, X.; Semitekolos, D.; Charitidis, C.A.; Dong, H. Enhanced properties of PAN-derived carbon fibres and resulting composites by active screen plasma surface functionalisation. Plasma Process. Polym. 2020, 17, 1900252. [CrossRef]

30. Semitekolos, D.; Kainourgios, P.; Jones, C.; Rana, A.; Koumoulos, E.P.; Charitidis, C.A. Advanced carbon fibre composites via poly methacrylic acid surface treatment; surface analysis and mechanical properties investigation. Compos. Part B Eng. 2018, 155, 237-243. [CrossRef]

31. Oliveux, G.; Dandy, L.O.; Leeke, G.A. Current status of recycling of fibre reinforced polymers: Review of technologies, reuse and resulting properties. Prog. Mater. Sci. 2015, 72, 61-99. [CrossRef]

32. The European Commission. The European Green Deal COM/2019/640 Final. 2019. Available online: https://eur-lex.europa.eu/legal-content/EN/TXT/?uri=COM\%3A2019\%3A640\%3AFIN (accessed on 22 May 2020).

33. Jacob, A. Composites can be recycled. Reinf. Plast. 2011, 55, 45-46. [CrossRef]

34. Initiative, L.C. New Report: The 2019 Annual Progress Report of the Life Cycle Initiative. 2019. Available online: https://www.lifecycleinitiative.org/ (accessed on 29 May 2020).

35. ISO. ISO 14001:2015 Environmental Management Systems-Requirements with Guidance for Use; International Organization for Standardization: Geneva, Switzerland, 2015.

36. Donnelly, K.; Beckett-Furnell, Z.; Traeger, S.; Okrasinski, T.; Holman, S. Eco-design implemented through a product-based environmental management system. J. Clean. Prod. 2006, 14, 1357-1367. [CrossRef]

37. Singh, A.V.; Laux, P.; Luch, A.; Sudrik, C.; Wiehr, S.; Wild, A.-M.; Santomauro, G.; Bill, J.; Sitti, M. Review of emerging concepts in nanotoxicology: Opportunities and challenges for safer nanomaterial design. Toxicol. Mech. Methods 2019, 29, 378-387. [CrossRef]

38. Kyriakidou, K.; Brasinika, D.; Trompeta, A.F.A.; Bergamaschi, E.; Karoussis, I.K.; Charitidis, C.A. In vitro cytotoxicity assessment of pristine and carboxyl-functionalized MWCNTs. Food Chem. Toxicol. 2020, 141, 111374. [CrossRef]

39. EU. A Clean Planet for all A European Strategic Long-Term Vision for a Prosperous, Modern, Competitive and Climate Neutral Economy. 2018. Available online: https:/eur-lex.europa.eu/legal-content/EN/TXT/PDF/ ?uri=CELEX:52018DC0773\&from=EN (accessed on 22 May 2020).

40. SWD. Report from the Commission to the European Parliament, the Council, the European Economic and Social Committee and the Committee of the Regions on the Implementation of the Circular Economy Action Plan. 2019. Available online: https://ec.europa.eu/environment/circular-economy/pdf/report_ implementation_circular_economy_action_plan.pdf (accessed on 22 May 2020).

41. 1999/31/EC. 1999/31/EC on the Landfill of Waste. 1999. Available online: https://eur-lex.europa.eu/legalcontent/EN/TXT/?uri=CELEX\%3A31999L0031 (accessed on 22 May 2020).

42. 94/62/EC. European Parliament and Council Directive 94/62/EC of 20 December 1994 on Packaging and Packaging Waste. 1994. Available online: http://eur-lex.europa.eu/legal-content/EN/NOT/?uri=celex: 31994L0062 (accessed on 22 May 2020).

43. 2000/53/EC. Directive 2000/53/EC on End-of Life Vehicles. Available online: https://eur-lex.europa.eu/legalcontent/EN/ALL/?uri=celex\%3A32000L0053 (accessed on 22 May 2020).

44. 2006/66/EC. Directive 2006/66/ec of the European Parliament and of the Council on Batteries and Accumulators and Waste Batteries and Accumulators and Repealing Directive 91/157/EEC. 2006. Available online: https://eur-lex.europa.eu/LexUriServ/LexUriServ.do?uri=OJ:L:2006:266:0001:0014:en:PDF (accessed on 22 May 2020).

45. 2012/19/EU. Directive 2012/19/eu of the European Parliament and of the Council on Waste Electrical and Electronic Equipment (WEEE). 2012. Available online: https://eur-lex.europa.eu/LexUriServ/LexUriServ.do? uri=OJ:L:2012:197:0038:0071:en:PDF (accessed on 22 May 2020).

46. COM. Commission Staff Working Document Communication from the Commission to the European Parliament, the Council, the European Economic and Social Committee and the Committee of the Regions a European Strategy for Plastics in a Circular Economy. 2018. Available online: https://eur-lex.europa.eu/ legal-content/EN/TXT/PDF/?uri=CELEX:52018SC0016\&from=RO (accessed on 22 May 2020). 
47. 333/2014 Regulation (EU). No 333/2014 of the European Parliament and of the Council of 11 March 2014 Amending Regulation (EC) No 443/2009 to Define the Modalities for Reaching the 2020 Target to Reduce CO2 Emissions from New Passenger Cars. 2014. Available online: https://op.europa.eu/en/publication-detail/-/ publication/5b971540-bc8f-11e3-86f9-01aa75ed71a1/language-en (accessed on 20 May 2020).

48. Heuss, R.; Muller, N.; van Sintern, W.; Starke, A.; Tschiesner, A. Lightweight, Heavy Impact; McKinsey E Company. 2012. Available online: https://www.mckinsey.com/ \{\}/media/mckinsey/dotcom/client_service/automotive (accessed on 22 May 2020).

49. Gardiner, G. Recycled carbon fiber update: Closing the CFRP lifecycle loop. Compos. Technol. 2014, 20, $28-33$.

50. Zhang, J.; Chevali, V.S.; Wang, H.; Wang, C.-H. Current status of carbon fibre and carbon fibre composites recycling. Compos. Part B Eng. 2020, 193, 108053. [CrossRef]

51. Xiarchos, I.; Morozinis, A.K.; Charitidis, C. Life cycle assessment and possible impacts of CFRPs for space applications. MATEC Web Conf. 2019, 304, 07006. [CrossRef]

52. Meng, F.; Pickering, S.; McKechnie, J. An Environmental Comparison of Carbon Fibre Composite Waste End-of-life Options. In Proceedings of the SAMPE Europe Conference 2018, Southampton, UK, 13 September 2018.

53. EC, Circular Economy Strategy. 2015. Available online: http://ec.europa.eu/environment/circular-economy/ index_en.htm (accessed on 10 October 2016).

54. Naqvi, S.R.; Prabhakara, H.M.; Bramer, E.A.; Dierkes, W.; Akkerman, R.; Brem, G. A critical review on recycling of end-of-life carbon fibre/glass fibre reinforced composites waste using pyrolysis towards a circular economy. Resour. Conserv. Recycl. 2018, 136, 118-129. [CrossRef]

55. Howarth, J.; Mareddy, S.S.R.; Mativenga, P.T. Energy intensity and environmental analysis of mechanical recycling of carbon fibre composite. J. Clean. Prod. 2014, 81, 46-50. [CrossRef]

56. Wu, T.; Zhang, W.; Jin, X.; Liang, X.; Sui, G.; Yang, X. Efficient reclamation of carbon fibers from epoxy composite waste through catalytic pyrolysis in molten ZnCl2. RSC Adv. 2019, 9, 377-388. [CrossRef]

57. Hall, S. End-of-life recycling options for glass fibre reinforced polymers. Plymouth Student Sci. 2016, 9, 68-94.

58. Hagnell, M.K.; Åkermo, M. The economic and mechanical potential of closed loop material usage and recycling of fibre-reinforced composite materials. J. Clean. Prod. 2019, 223, 957-968. [CrossRef]

59. Bachmann, J.; Hidalgo, C.; Bricout, S. Environmental analysis of innovative sustainable composites with potential use in aviation sector-A life cycle assessment review. Sci. China Technol. Sci. 2017, 60, 1301-1317. [CrossRef]

60. Lee, C.-K.; Kim, Y.-K.; Pruitichaiwiboon, P.; Kim, J.-S.; Lee, K.-M.; Ju, C.-S. Assessing environmentally friendly recycling methods for composite bodies of railway rolling stock using life-cycle analysis. Transp. Res. Part. D Transp. Environ. 2010, 15, 197-203. [CrossRef]

61. Khalil, Y.F. Comparative Environmental and Human Health Evaluations of Thermolysis and Solvolysis Recycling Technologies of Carbon Fiber Reinforced Polymer Waste. Waste Manag. 2018, 76, 767-778. [CrossRef] [PubMed]

62. Keith, M.; Oliveux, G.; Leeke, G. Optimisation of Solvolysis for Recycling Carbon Fibre Reinforced Composites. 2016. Available online: http://dspace.lib.cranfield.ac.uk/handle/1826/10334 (accessed on 30 June 2016).

63. Roux, M.; Eguémann, N.; Dransfeld, C.; Thiébaud, F.; Perreux, D. Thermoplastic carbon fibre-reinforced polymer recycling with electrodynamical fragmentation: From cradle to cradle. J. Thermoplast. Compos. Mater. 2015, 30, 381-403. [CrossRef]

64. Shuaib, N.A.; Mativenga, P.T. Energy demand in mechanical recycling of glass fibre reinforced thermoset plastic composites. J. Clean. Prod. 2016, 120, 198-206. [CrossRef]

65. Nakagawa Mitsutoshi, S.K. CFRP Recycling Technology Using Depolymerization Under Ordinary Pressure. 2014. Available online: https://www.hitachi-chem.co.jp/english/report/056/56.pdf\#page=5 (accessed on 22 May 2020).

66. EC-JRC. International Reference Life Cycle Data System (ILCD) Handbook-General Guide for Life Cycle Assessment-Detailed Guidance, 1st ed.; Publications Office of the European Union: Luxembourg, 2010; ISBN 978-92-79-19092-6. 
67. Weidema, B.P.; Bauer, C.; Hischier, R.; Mutel, C.; Nemecek, T.; Reinhard, J.; Vadenbo, C.O.; Wernet, G. The Ecoinvent Database: Overview and Methodology, Data Quality Guideline for the Ecoinvent Database Version 3. 2013. Available online: https://www.ecoinvent.org (accessed on 22 May 2020).

68. Kainourgios, P.; Kartsonakis, I.A.; Dragatogiannis, D.A.; Koumoulos, E.P.; Goulis, P.; Charitidis, C.A. Electrochemical surface functionalization of carbon fibers for chemical affinity improvement with epoxy resins. Appl. Surf. Sci. 2017, 416, 593-604. [CrossRef]

69. Dai, Q.; Kelly, J.; Elgowainy, A. Material Efficiencies and Recycling of Aluminum and Carbon Fiber Reinforced Plastics for Automotive Applications. Energy Syst. 2016. Available online: https://greet.es.anl. gov/publication-materials-automotive-2016 (accessed on 22 May 2020).

70. Griffing, E. Chemical Life Cycle Database. 2010. Available online: https://environmentalgenome.org/wpcontent/uploads/2017/09/ES_V4_triethylaluminum_2016-11-10_15-48.pdf (accessed on 22 May 2020).

71. Sidorina, A.I.; Gunyaeva, A.G. Market for Carbon Fibres and Composites Based on them. A review. Fibre Chem. 2016, 48, 306-310. [CrossRef]

72. Prakashkumar, P.; Chauhan, E.C.; Shah, D.S.N. Basics of Carbon Fiber-Business Opportunities; Lulu Publications: Raleigh, NC, US, 2019; Chapter 2; ISBN 978-0-359-87231-2.

73. Yang, Y.; Boom, R.; Irion, B.; van Heerden, D.-J.; Kuiper, P.; de Wit, H. Recycling of composite materials. Chem. Eng. Process. Process. Intensif. 2012, 51, 53-68. [CrossRef]

74. Seghini, M.C. Investigation into the Mechanical Properties and Fibre/Matrix Interface Optimization for Next Generation of Basalt-Plant Fibre Hybrid Composites, Sapienza; University of Rome: Rome, Italy, 2020.

75. Witik, R.A.; Teuscher, R.; Michaud, V.; Ludwig, C.; Månson, J.-A.E. Carbon fibre reinforced composite waste: An environmental assessment of recycling, energy recovery and landfilling. Compos. Part A Appl. Sci. Manuf. 2013, 49, 89-99. [CrossRef]

76. Dong, P.A. Economic and environmental assessment of recovery and disposal pathways for CFRP waste management. Resour. Conserv. Recycl. 2018, 133, 63-75. [CrossRef]

77. Pickering, S.J. Recycling technologies for thermoset composite materials-Current status. Compos. Part A Appl. Sci. Manuf. 2006, 37, 1206-1215. [CrossRef]

78. Khalil, Y.F. Eco-efficient lightweight carbon-fiber reinforced polymer for environmentally greener commercial aviation industry. Sustain. Prod. Consum. 2017, 12, 16-26. [CrossRef]

79. Dahlbo, H.; Bachér, J.; Lähtinen, K.; Jouttijärvi, T.; Suoheimo, P.; Mattila, T.; Sironen, S.; Myllymaa, T.; Saramäki, K. Construction and demolition waste management-A holistic evaluation of environmental performance. J. Clean. Prod. 2015, 107, 333-341. [CrossRef]

80. Rybicka, J.; Tiwari, A.; Leeke, G.A. Technology readiness level assessment of composites recycling technologies. J. Clean. Prod. 2016, 112, 1001-1012. [CrossRef]

81. Pickering, S. Recycling Thermoset Composite Materials. In Wiley Encyclopedia of Composites; John Wiley \& Sons, Inc.: Hoboken, NJ, USA, 2012; Volume 42, ISBN 9781118097298.

82. Dauguet, M.; Mantaux, O.; Perry, N.; Zhao, Y.F. Recycling of CFRP for High Value Applications: Effect of Sizing Removal and Environmental Analysis of the SuperCritical Fluid Solvolysis. Procedia CIRP 2015, 29, 734-739. [CrossRef]

83. Lee, S.; Norman, J.; Gunasekaran, S.; van Laack, R.L.J.; Kim, B.; Kauffman, R. Use of electrical conductivity to predict water-holding capacity in post-rigor pork. Meat Sci. 2000, 55, 385-389. [CrossRef]

84. Prinçaud, M.; Aymonier, C.; Loppinet-Serani, A.; Perry, N.; Sonnemann, G. Environmental Feasibility of the Recycling of Carbon Fibers from CFRPs by Solvolysis Using Supercritical Water. ACS Sustain. Chem. Eng. 2014, 2, 1498-1502. [CrossRef]

85. Leu, S.-Y.; Yang, T.-H.; Lo, S.-F.; Yang, T.-H. Optimized material composition to improve the physical and mechanical properties of extruded wood-plastic composites (WPCs). Constr. Build. Mater. 2012, 29, 120-127. [CrossRef]

86. Doka, G. Life Cycle Inventories of Waste Treatment Services, Dübendorf. 2003. Available online: https: //www.doka.ch/13_I_WasteTreatmentGeneral.pdf (accessed on 22 May 2020).

87. Forster, P.; Ramaswamy, V.; Artaxo, P.; Berntsen, T.; Betts, R.; Fahey, D.; Haywood, J.; Lean, J.; Lowe, D.; Myhre, G.; et al. Changes in atmospheric constituents and in radiative forcing. In Climate Change 2007: The Physical Science Basis. Contribution of Working Group I to the Fourth Assessment Report of the Intergovernmental Panel on Climate Change; Solomon, S., Qin, D., Manning, M., Chen, Z., Marquis, M., Averyt, K., Tignor, M., Miller, H., Eds.; Cambridge University Press: Cambridge, UK, 2007. 
88. Hauschild, M.Z.; Goedkoop, M.; Guinée, J.; Heijungs, R.; Huijbregts, M.; Jolliet, O.; Margni, M.; De Schryver, A.; Humbert, S.; Laurent, A.; et al. Identifying best existing practice for characterization modeling in life cycle impact assessment. Int. J. Life Cycle Assess. 2013, 18, 683-697. [CrossRef]

89. Bonou, A.O.S.I. Decision Uncertainties in LCA: Database, Software \& LCIA Methodology Choice. In Proceedings of the 23th SETAC Europe Annual Meeting, Glasgow, UK, 12-16 May 2013.

90. Herrmann, I.T.; Moltesen, A. Does it matter which Life Cycle Assessment (LCA) tool you choose?-A comparative assessment of SimaPro and GaBi. J. Clean. Prod. 2015, 86, 163-169. [CrossRef]

91. Jolliet, O.; Margni, M.; Charles, R.; Humbert, S.; Payet, J.; Rebitzer, G.; Rosenbaum, R. IMPACT 2002+: A new life cycle impact assessment methodology. Int. J. Life Cycle Assess. 2003, 8, 324-330. [CrossRef]

92. Behrens, A. The Climate Change Impact of Material Use. Intereconomics 2016, 51, 209-212. [CrossRef]

93. Hermansson, F.; Janssen, M.; Svanström, M. Prospective study of lignin-based and recycled carbon fibers in composites through meta-analysis of life cycle assessments. J. Clean. Prod. 2019, 223, 946-956. [CrossRef]

94. Zoghi, M. The International Handbook of FRP Composites in Civil Engineering; CRC Press: Boca Raton, FL, USA, 2014.

95. Chua, M.H. Understanding Aerospace Composite Components Supply Chain Carbon Emissions. In Proceedings of the Irish Manufacturing Conference (IMC32), Belfast, UK, 3 September 2015.

96. Meng, F.; McKechnie, J.; Turner, T.; Wong, K.H.; Pickering, S.J. Environmental Aspects of Use of Recycled Carbon Fiber Composites in Automotive Applications. Environ. Sci. Technol. 2017, 51, 12727-12736. [CrossRef]

97. Trompeta, A.-F.; Koklioti, M.A.; Perivoliotis, D.K.; Lynch, I.; Charitidis, C.A. Towards a holistic environmental impact assessment of carbon nanotube growth through chemical vapour deposition. J. Clean. Prod. 2016, 129, 384-394. [CrossRef]

98. EEA. CO2 Intensity of Electricity Generation. 2017. Available online: https://www.eea.europa.eu/data-andmaps/data/co2-intensity-of-electricity-generation (accessed on 1 June 2020).

99. SBI50. Japan's Current Progress of GHG Reduction. 2019. Available online: https://unfccc.int/sites/default/ files/resource/Japan_MA2019_presentation.pdf (accessed on 1 June 2020).

100. IEA. Key Energy Statistics. 2019. Available online: https://www.iea.org/countries/japan (accessed on 1 June 2020).

101. EEA. European Union Emission Inventory Report 1990-2017 under the UNECE Convention on Long-range Transboundary Air Pollution (LRTAP). EEA Technical Report No 9/2019. Copenhagen. 2019. Available online: https://www.eea.europa.eu/data-and-maps/indicators/eea32-persistent-organic-pollutantpop-emissions-1/eea-2010-.-european-union (accessed on 22 May 2020).

102. Rubino, F.; Nisticò, A.; Tucci, F.; Carlone, P. Marine Application of Fiber Reinforced Composites: A Review. J. Mar. Sci. Eng. 2020, 8, 26. [CrossRef]

103. Meng, F.; McKechnie, J.; Pickering, S.J. An assessment of financial viability of recycled carbon fibre in automotive applications. Compos. Part A Appl. Sci. Manuf. 2018, 109, 207-220. [CrossRef]

104. Job, S.; Mativenga, P.; Shuaib, N.A.; Oliveux, G.; Leeke, G.; Pickering, S. Composites Recycling-Where Are We Now? Composites UK Ltd.: Berkhamsted, UK, 2016.

105. Miseljic, M.; Olsen, S.I. LCA of Nanomaterials. In Life Cycle Assessment; Springer International Publishing: Cham, Switzerland, 2018; pp. 817-833.

106. Miseljic, M.; Olsen, S.I. Life-cycle assessment of engineered nanomaterials: A literature review of assessment status. J. Nanoparticle Res. 2014, 16, 2427. [CrossRef]

107. Thangadurai, T.D.; Manjubaashini, N.; Thomas, S.; Maria, H.J. Nanomaterials Research and Development; Springer: Cham, Switzerland, 2020; pp. 203-210.

108. Upreti, G.; Rajive, D.; Naidu, S.; Atuahene, I.; Sawhney, R. Life Cycle Assessment of Nanomaterials. In Green Processes for Nanotechnology: From Inorganic to Bioinspired Nanomaterials; Springer: Cham, Switzerland, 2015; pp. 393-408.

109. OECD. Incineration of Waste Containing Nanomaterials. In Nanomaterials in Waste Streams: Current Knowledge on Risks and Impacts; OECD Publishing: Paris, France, 2016. [CrossRef]

110. Gavankar, S.; Suh, S.; Keller, A.A. The Role of Scale and Technology Maturity in Life Cycle Assessment of Emerging Technologies: A Case Study on Carbon Nanotubes. J. Ind. Ecol. 2015, 19, 51-60. [CrossRef] 
111. OECD. Waste: Municipal Waste. In OECD Environmental Statistics (Database); OECD: Paris, France, 2020.

112. Duflou, J.R.; De Moor, J.; Verpoest, I.; Dewulf, W. Environmental impact analysis of composite use in car manufacturing. CIRP Ann. 2009, 58, 9-12. [CrossRef] 